\title{
The Power of the Supreme Court in the Age of the Positive State: A Preliminary Excursus Part One: On Candor and the Court, or, Why Bamboozle the Natives?
}

\author{
Alan Scheflin \\ Santa Clara University School of Law, ascheflin@scu.edu \\ Arthur Selwyn Miller
}

Follow this and additional works at: http://digitalcommons.law.scu.edu/facpubs

Part of the Law Commons

\footnotetext{
Automated Citation

Alan Scheflin and Arthur Selwyn Miller, The Power of the Supreme Court in the Age of the Positive State: A Preliminary Excursus Part One: On Candor and the Court, or, Why Bamboozle the Natives?, 1967 Duke L.J. 273 (1967),

Available at: http://digitalcommons.law.scu.edu/facpubs/685 


\title{
THE POWER OF THE SUPREME COURT IN THE AGE OF THE POSITIVE STATE: A PRELIMINARY EXCURSUS PART ONE: ON CANDOR AND THE COURT, OR, WHY BAMBOOZLE THE NATIVES?
}

\author{
ARTHUR SELWYN MILLER* \\ ALAN W. ScheFLIN $\dagger$
}

The time is past in the history of the world when any living man or body of men can be set on a pedestal and decorated with a halo. ....

It is not good, either for the country or the [Supreme] Court, that the part played by the Court in the life of the country should be shrouded in mystery.

\section{INTRODUCTION}

7 HIS ARTICLE is in two parts. In main thrust, it is concerned with the power (in a political sense) of the United States Supreme Court in the modern era. Part One, published here, is a discussion of the symbolic role of the Court and the alleged need that it outwardly adhere to the Blackstonian declaratory theory of law. In this preliminary foray into a complicated subject matter, we intend no more than to suggest a few hypotheses which may, when subjected to empirical test, result in a greater understanding of the High Bench. Part Two, which will appear in a subsequent issue, considers the necessity for the Court to adapt itself to changing reality if it is to retain whatever power it may presently have. Running through both essays is the theme that much more factual data is required before an adequate understanding of the Court can be attained. Both parts of this article attempt to identify some of

- A.B. 1938, Willamette University; LL.B. 1949, Stanford Law School; J.S.D. 1959, Yale Law School. Professor of Law, The George Washington University.

† B.A. 1963, University of Virginia; LL.B. 1966, The George Washington University Law School; LL.M. Candidate, Harvard Law School.

$\ddagger$ Frankfurter, The Supreme Court and the Public, 83 Forum 329-30 (1930). 
the many factors affecting the prestige and power of the nine men who sit in the Marble Palace; hence, the subtitle, "a preliminary excursus."

The essential question is one of political power, by which is meant the ability or capacity to make decisions affecting the values of Americans. 1 The prestige of the Court, the esteem in which it is held, can be of importance only insofar as it is capable of translation into power in a political sense. That the Court exercises such power is assumed without argument, and there remains only the question as to how much and on what occasions.

We do not intend to "talk lightly of the dignity" of the Supreme Court $^{2}$ but merely to try to ascertain some truths about it. No suggestion is made that the truth is easily come by. Far from it. Difficulties are initially presented by rigid internal secrecy which, Justice Frankfurter maintained, is "essential to the effective functioning of the Court."3 Furthermore, as Ernest Nagel has observed, there is no such thing as a simple and, at the same time, adequate explanation of any phenomenon or institution. 4 To know government, including the Supreme Court, one must know history and economics, sociology and political science, law and psychology, and divers other matters. Nonetheless, it is possible to broach a greater understanding of the Court and at least pose some of the questions upon which correct and vitally important answers are dependent.5

\footnotetext{
${ }^{1}$ See Lasswell \& Kaplan, Power and Society 75 (1950); Rosinski, Power and Human Destiny (1965); Russele, Power (1938); Fuller, Irrigation and Tyranny, 17 STAN. L. REv. 1021 (1965).

2 The phaseology is taken from a statement by Charles Evans Hughes, who said: "I reckon him one of the worst enemies of the community who will talk lightly of the dignity of the bench." Quoted in Mason, Myth and Reality in Supreme Court Decisions, 48 VA. L. REv. 1385, 1387 (1962).

At the outset, it is desirable to postulate a basic value position: that it is the duty of legal scholars to pursue the "truth" even though truth may well be "subversive of the established order." Aiken, $A$ Virtue in Question, New York Review of Books, June 9, 1966, p. 10, 11. See Szent-Györgyi, Science, Biology and Human Relations, The Minority of One, May 1966, p. 10, 11.

"Frankfurter, Justice Roberts and the "Switch in Time," in AN AUTOBrography or THE SUPREME COURT 244 (Westin ed. 1963).

4 See Nagel, The Structure of Sctence: Problems in the Logic of Scientific ExpLANation 26 (1961).

${ }^{5}$ As Mr. Justice Frankfurter opined, "in law also the right answer usually depends on putting the right question." Estate of Rogers v. Commissioner, 320 U.S. 410, 413 (1943). "[A]nswers are not obtained by putting the wrong question and thereby begging the real one." Priebe \& Sons v. United States, 332 U.S. 407, 420 (1947).
} 
This may be done even though relevant factual data is simply not available to enable one to "prove" his conclusion definitively.

One of the hallmarks of the mid-twentieth century is an apparent need to re-define terms and re-evaluate the operating principles of the disciplines which play a basic role in structuring our lives. ${ }^{6}$ Change is in the air, a constant of the social and intellectual order. Accordingly, re-examination of the legal system, haphazard and incomplete though it may be, has roots running at least as far back as the legal realist movement of the 1920s and '30s; it is a part of the "revolt against formalism" noted by Morton White. T The realists, by destroying nineteenth century conceptualism, left the legal system in general and the judicial process in particular, in a state of intellectual disarray. They were not system builders; they were iconoclasts who ripped the facade off classical jurisprudence but who did nothing to replace it with a more acceptable (that is, intellectually satisfying) conception of the nature of the judicial process. As Professor Wilfred Rumble has said, "their dissatisfaction with the traditional standard of judicial behavior was never translated into an explicit and sustained examination of the norms which ought to replace stare decisis as the regulator of judicial decisions." 8 We do not undertake such an examination here; what follows has a far lesser goal-a suggestion of the unfulfilled need for empirical data about the Supreme Court accompanied by a further suggestion that the Court has lost, and will continue to lose, power vis-à-vis the other organs

\footnotetext{
- Several examples come to mind: in literature, the rise of the existentialist novel picturing the despair and anguish of individual existence and the impotence of a "community ethic" to solve the responsibility for one's own essence; in the dramatic arts, the theatre of the absurd bringing to the stage essentially the same point the existentialist writers have dwelt upon; in philosophy, the abdication of the role of system-builder and explainer of the function of man, with a resultant rise of linguistic analysis and ordinary language philosophy in an attempt to ascertain the nature of a philosophical question; in religion, the God-is-dead movement challenging the efficacy of traditional religion in a secular age to perform its role as moral conscience for man and his spiritual mentor; in science, new breakthroughs to new levels of understanding especially in the areas of internal medicine and space technology; and in society, the frequent riots on college campuses, the civil rights movement, and the turn toward the new hallucinogenic drugs and the insights they purportedly give.

7 White, Social Thought in America 11 (1949). See Commager, The American Mind 359-90 (1950).

${ }^{8}$ Rumble, The Paradox of American Legal Realism, 75 Etwics 166 (1965). (Emphasis in original.) See also Rumble, Legal Realism, Sociological Jurisprudence and $M r$. Justice Holmes, 26 J. HisT. IDEAs 547 (1965).
} 
of government (particularly the Executive) in this era of the Positive State. ${ }^{9}$

NATURE of the Inquiry: A MatTer of JURISPRUdence

"[T]he question of jurisprudence," it has recently been asserted, is "what, in general, is a good reason for decision by a court of law."10 At best, this is a dubious proposition. Aside from the difficulty that concealed within its simplistic veneer lurk several very different and very troublesome inquiries, ${ }^{11}$ there remains the fact that it can' only be based upon the unwarranted assumption that the judiciary is still the center of the legal universe, something which has not been true in Anglo-American law for decades. Perhaps at one time analysis of adjudication could validly be termed the problem for jurisprudents, but the governmental emphasis now has shifted in official decisionmaking to legislatures and, of even more importance, to the Executive Branch. Accordingly, even though, as Dean Levi recently noted, legal education (and thus, the law reviews and scholarly discourse) is still "court oriented,"12 that orientation is excessive and in. creasingly non-reflective of legal reality. Hence, although this paper further adds to the already too large literature on the Supreme Court, in main thrust it suggests that further single-minded casuistry about the Court is on the whole unrewarding in attaining a greater understanding about the judiciary and that the need, accordingly, exists for empirical data and hypotheses which will add more meaningful dimensions to the sparse existing learning. We should take as our goal the increase in understanding of the Supreme Court, rather than the more limited task of being able better to predict the course of judicial decision, although no doubt greater understanding will

The concept of the Positive State is outlined in Miller, Constitutional Revolution Consolidated: The Rise of the Positive State, 35 Gro. WASH. L. REv. 172 (1966).

${ }^{10}$ Dworkin, Does Law Have a Function? A Comment on the Two-level Theory of Decision, 74 YALE L.J. 640 (1965). (Emphasis in original.)

${ }^{11}$ Professor Dworkin continues by noting that the question of what is a good reason for a decision by a court is one way of asking "what is law?" Ibid. But that seems too simple a formulation. The question, "What is law?", is itself reducible to at least the following questions: (1) What is a legal system? (2) What is a valid law? (3) What is the essence, or nature of law? (4) What is a good reason for a judicial decision? (5) What are the pre-conditions for the maintenance of a legal order? See Sartorius, The Concept of Law, LII/Z ARchives for Philosophy of LAw ANd SOCIAL Philosophy 161, 162 (1966).

12 Levi, Law Schools and the Universities, 17 J. Lecal ED. 243, 248 (1965). 
lead to more accurate predictions. As Professor Lon L. Fuller recently said:

There may be said to exist two philosophies of science. The one sees the aim of science as understanding; the other as prediction. The first regards prediction as a by-product of understanding; we acquire the ability to predict events as our minds penetrate into the causes that underlie the happenings of nature. The adherents of the opposed theory see "understanding" as an illusory, metaphysical trapping superfiuously tacked on the essential goal of acquiring predictive knowledge. ${ }^{13}$

Fuller opts for understanding. The point here is simply that there is a pressing need for a true conception of the nature of the Court as a politico-legal institution in a broader societal matrix before we can predict what that institution will do. The need therefore is for data about the Court and its effect on the populus. There is abundant criticism of the Court today purely on the grounds that it has abandoned its (assertedly) proper institutional role and has encroached upon the private domains of the other organs of government. Such criticism, we suggest, is meaningless without a settled notion of what the proper role of the Court is vis-à-vis the other organs of government. It is to further that initial inquiry that we call for data about the Court in its institutional setting so that a greater understanding of what the Court is supposed to do may be obtained.

To accomplish that greater understanding will require drawing upon insights and learning from allied disciplines, particularly the behavioral and social sciences. But here, as in the better known casuistical exercises about the Supreme Court, the necessary insights are scanty at best and non-existent at worst. Available are some tentative explorations into the terra incognita of judicial behavior but nothing of a comprehensive and systematic nature. ${ }^{14}$ Neither the lawyers (and political scientists) who confine their study of the high tribunal to the published opinions of the Justices nor their colleagues in the behavioral sciences have yet produced the answers. ${ }^{15}$ Students of the Court are just now beginning to ask some

${ }^{18}$ Fuller, An Afterword: Science and the Judicial Process, 79 HaRv. L. REv. 1604, 1623-24 (1966). (Emphasis in original.)

I4 See, e.g., Schubert, Judiclal Behavior: A Reader in Theory aNd Research (1964).

${ }^{15}$ How many lawyers, questioned Chief Justice Roger J. Traynor, have any "real 
of the correct questions. ${ }^{15 \mathrm{a}} \mathrm{By}$ and large these questions are noncasuistical and non-doctrinal; they provide a means of breaking out of the narrow navel-gazing that has so preoccupied legal studies in the past (and even the present) and enable one to perceive the Court as a unit of government and a societal institution. First of all, some attention must be paid to the question: What is a question (or problem)? The task of identifying the correct questions itself is not an easy exercise, as Felix Cohen demonstrated in 1929 and as Mayo and Jones have recently developed. ${ }^{16}$

\section{Three Tentative Hypotheses}

To provide a point of departure for what follows, a recent paper of Professor Paul Mishkin on the Linkletter case ${ }^{17}$ has been selected as a statement of the point of view substantially at variance with what is suggested below. ${ }^{18}$ In his article Professor Mishkin, in the context of a recent criminal law decision, thoughtfully analyzes the problems inherent in prospective overruling of constitutional doctrine by the Supreme Court. During his' exposition he asserts that there is symbolic value in the Blackstone "declaratory" theory of law, which he believes may be "in part myth [but] . . . which can be sacrificed only at substantial cost." ${ }^{19}$ Apparently the cost he has in mind is public disrespect for, and lack of confidence in, the Supreme Court. In other words, we understand him to say that if it became generally known that the Justices were something less than the coldly rationalistic, automatonistic judges extolled by Blackstone, the prestige (and thus the power) of the Court would plummet. The image, in short, is deemed an important element of the power of the Court. His assertions are made without reference to empirical data, and therefore his conclusions, it seems, are derived intuitively rather than "scientifically." With all deference, intuiting conclusions about the prestige and resultant power of the Supreme

awareness of how courts arrive at a decision?" Traynor, Badlands in an Appellate Judge's Realm of Reason, 7 UTAH L. REv. 157, 158 (1960).

152 See text accompanying note 96 infra.

${ }^{10}$ Cohen, What is a Question?, in The Legal Conscience: Selected Papers of Felix S. Cohen 3 (L. Cohen ed. 1960); Mayo \& Jones, Legal-Policy Decision Process: Alternative Thinking and the Predictive Function, 33 GEo. Wash. L. REv. 318 (1964).

${ }^{17}$ Linkletter v. Walker, 381 U.S. 618 (1965).

${ }^{28}$ Mishkin, Foreword: The High Court, the Great Writ, and the Due Process of Time and Law, 79 HARV. L. REv. 56, 62-70 (1965). 20 Id. at 63 . 
Court does not meet the requirement of reliable information upon which judgments may be made and a greater understanding reached. The same thing may be said about the need for hard factual data in evaluating the Court, as has been said by the Court itself in rendering opinions. For example, the reluctance to issue true advisory opinions is based, according to Professor (later Justice) Felix Frankfurter, precisely upon the lack of a factual context in which the legal concepts may be seen. ${ }^{20}$ This does not mean, of course, that the Court does not issue advisory opinions; it does on occasion but does not call them that. ${ }^{21}$ However, the opinion is at least partially couched in a factual setting. The point here is that Professor Mishkin's conclusions are not convincingly supportable except upon an empirical foundation. Professor Mishkin is not directing himself toward a closely reasoned conceptual theory about the basis of a constitutional (or other) doctrine where the process of argumentation is of prime importance. Nor is he attempting to give an historical explanation of a phenomenon of the Court where citation to leading authorities is decisive. Rather, he is attempting to explain a public reaction to the existence and activity of an august governmental body and is drawing conclusions from an intuitive idea of how people regard the Court. In short, Professor Mishkin is asking the kinds of questions that he, by himself, cannot answer since he is directing his inquiry beyond reason and beyond history to contemporary fact. And without those facts there is little support for his opinion. ${ }^{22}$

We certainly do not mean to suggest that Professor Mishkin's analysis is not a useful discussion containing valuable insights. However, given the dearth of empirical inquiry, the difficulty is

${ }^{20}$ See Frankfurter, $A$ Note on Advisory Opinions, 37 Harv. L. Rev. 1002 (1924).

${ }^{21}$ See, e.g., Johnson v. New Jersey, 384 U.S. 719 (1966); Miranda v. Arizona, 384 U.S. 436 (1966). Insofar as Linkletter v. Walker, 381 U.S. 618 (1965), and Tehan v. United States, 382 U.S. 406 (1966), purport to settle a general, as distinguished from a particular, rule, they too may be considered as a form of advisory opinion. In other words, they determined the fate of all those caught by the prospective overruling determination without the benefit of a specific ruling on the merits of each individual case.

22 The fallacy involved has been referred to as the "intuitionist fallacy." Professor Mishkin is asking us to accept his position without offering empirical data to back up his conclusions. If we suppose that someone else comes along and asks us to believe the contrary, also without data, we may believe either one since there is no criteria for proper choice. This puts one in the same situation as the fabled donkey who, in trying to choose which of two piles of hay to eat where both piles were the same distance away, died on the spot before he could make up his mind which one to choose. 
an inability to speak with any authority about matters resting solely upon facts that are not presently in evidence. This is only a small part of the larger problem of ascertaining the role of the Supreme Court in the American polity.

In an attempt to discover what some students of the Court believe about the symbolic value of the declaratory theory of law, a questionnaire was sent to a selected group of people, including lawyers, political scientists, and a newspaperman. The questionnaire, which is reproduced in the appendix ${ }^{23}$ was drafted in somewhat imprecise terms, so as to cover greater ground without imposing upon the recipients' time. Approximately 150 letters were sent and replies were received from about one-third, some very brief (just a few words) and some quite long and extensive. ${ }^{44}$ While no effort was made to question lay members of the public, there was an attempt to reach both the "activists" and the advocates of "self-restraint." Of some interest, perhaps, in this search for critical fact is that there were no replies from the most vociferous modern critics of the Court.

We are well aware of a great many difficulties in our survey. Perhaps the major defect is that it does not poll the layman but rather attempts to ascertain what members of the profession, and especially students of the Court, are thinking about the problems discussed by Professor Mishkin. There is a pressing need for empirical data reflecting the Iay opinion on these matters ${ }^{25}$ since the "hearsay" we have gleaned is far from sufficient to settle the matters in issue. The other major defect, if it can be called a defect, is the vague and ambiguous nature of the questions. Thus, the first question, which calls for an opinion as to why the judiciary is held in high esteem, assumes that the Court is widely respected and does not differentiate whether such regard is for the activities of the Court or for its general institutional setting. The second and third questions, which request opinions about the necessity or desirability of public ignorance of "legal realism," assume that a unified set of beliefs constitute

\footnotetext{
${ }^{23}$ See page 301 infra.

${ }^{24} \mathrm{~A}$ few of the more thougbtful and provocative of the replies are reproduced beginning at page 302 infra.

${ }^{25}$ Since the main text was written, we have become aware of some as yet unpublisbed studies which do attempt to assay lay opinion about the Supreme Court and its decision-making. Dolbeare, The Public Views the Supreme Court, in LAw AND Polmtics IN THE SUPREMe Court (Jacob ed. 1967); Dolbeare \& Hammond, The Political Party Basis of Attitudes Toward the U.S. Supreme Court, 1966 (unpublished manuscript, The University of Wisconsin).
} 
that philosophy; such a set of beliefs of course does not exist. But this ambiguity was intentional and has had the advantage of allowing more freedom in answering. The questions, sent to students of the Court, were not intended to "count noses" scientifically on basic propositions but rather to serve as a vehicle for the expression of thoughts on the topics mentioned in the questions.

The results of the survey, admittedly sparse and by no means unanimous, ${ }^{26}$ seem to indicate that experts hold the following beliefs about the Supreme Court and the symbolic value of the declaratory theory: (1) the American people generally have little or no knowledge about how the Court operates; (2) they probably do not care and would not take the trouble to find out; and (3) they are probably more interested in what the Court has done in a substantive sense, rather than how it accomplishes the result. No one, it is important to note, knew of any studies which had developed empirical evidence on these matters.

\section{A First Hypothesis}

From the survey, the following tentative hypothesis has been formulated: The prestige of the Supreme Court has little or nothing to do with its symbolic role as such-court qua court, nine wise men, cult of the robe, et cetera-but rather with what it does. Stated another way, it is hypothesized that the American people accord a high respect to the Supreme Court when there is basic agreement with the results the Court reaches in its decisions. From this hypothesis it follows that since prestige is important only insofar as it contributes to its power, the Supreme Court's power depends upon what it does and not how its decisions are made.

Even among those who make a practice of studying and following the course of Court decisions, in other words, there seems to be considerable agreement that what in recent years has been termed "principled decision-making"27 is of importance only to the cognoscenti-and, of them, only to a relatively small percentage. The

\footnotetext{
${ }^{20}$ No attempt has been made to collate the results of the survey in neat tables. What is suggested in this paper gives the tenor of the bulk of the answers. Some dissents were received. See Appendix, page 302 infra.

${ }^{27} \mathrm{By}$ and large this group is made- up of votaries in the cult of Justice Frankfurter. What they have failed to see will be developed more fully in Part Two, namely, that the Supreme Court as they envisage it never existed and also that they are calling for a return to mechanical jurisprudence, however sophisticated its current version may be.
} 
handful who seek an elegantia juris-those who demand the aesthetic satisfaction of closely reasoned, appropriately documented opinions written in immortal prose and ideal fashion-do not seem to represent anyone other than themselves. They do not speak for those lawyers and persons who must predict what the Court will do and rely on what it has done, because predictability is a function of change and of understanding and not aesthetic symmetry. Predictability does not depend upon the perfectly symmetrical legal system which progresses by deduction but rather upon the ability to read correctly the temper of the age and to calculate the logarithm between legal doctrine and social change. In final analysis, those who seek symmetry alone are asking for the impossible. They mistake the nature of adjudication, historical and contemporaneous, and fail to accord necessary emphasis to the fact that the Court in its constitutional adjudications is as much-or more-a political organ than a legal body. In short, there is a consistent failure to note that judicial decisions in constitutional cases should be evaluated more by whether they meet standards of sociological arbitrariness than by their logical consistency. ${ }^{28}$ This is not to say, of course, that one should applaud sloppily written opinions but merely to point out that, as the Court itself said in connection with public utility rate-making, "it is the result reached not the method employed which is controlling ...."20 Furthermore, throughout American history the Justices themselves apparently have been more interested in results than in methodology. One need only compare the reasoning used by Chief Justice Marshall in different opinions to find evidence for that proposition; brief reference to Marbury's Case ${ }^{30}$ and McCulloch's Case ${ }^{31}$ will quickly reveal how he changed his method to suit the problem. At no time in American constitutional history can it be said that the demand for "principled decision-making" has been fulfilled. This should not be taken to mean that such an ideal should not be striven for, but simply that here, as otherwise, a man's reach inevitably exceeds his grasp. Perhaps it would be better to take as the ideal something within the capacities of the human mind and something which is more in

\footnotetext{
${ }^{28}$ See Miller, Mulkey v. Reitman: A Brave But Futile Gesture?, 14 U.C.L.A.L. REv. 51 (1966).

${ }^{\circ}$ Federal Power Comm'n v. Hope Natural Gas Co., 320 U.S. 591, 602 (1944) (opin. ion of the Court by Douglas, J.).

${ }^{30}$ Marbury v. Madison, 5 U.S. (1 Cranch) 137 (1803).

s1 McCulloch v. Maryland, 17 U.S. (4 Wheat.) 316 (1819).
} 
accord with what people apparently want from courts. Furthermore, this does not mean that judges are free to rule according to their personal whims; they are bound by the institutional setting of the Court, part of which is adherence to the received norms from the past. However, those pre-existing norms cannot be said to be specifically controlling, for constitutional rules and principles run in pairs of opposites. A ruling on the merits may be said to synthesize creatively the choice made from those opposites.

\section{A Second Hypothesis}

If one assumes the validity of the first tentative hypothesis, then a second may be suggested: The Supreme Court has power to the extent that it articulates deep-set valeus (preferences) of the American people. Obviously, this is closely allied to the first, for if the prestige (or power) of the Court is more dependent upon what is decided than how the Justices reason, then it ineluctably follows that power varies with the result reached. In other words, decisions on different issues have a differing impact upon the manner in which people order their affairs. It is one thing to say that the Court has an impact upon the litigants before it; usually (although not necessarily always) $)^{32}$ it doubtless does have. The Danny Escobedos, Dollree Mapps, Glarence Gideons, and many other individuals, are eloquent testimony to that. But it is quite another thing to say, as is sometimes done, that "the law of the land" thus enunciated is followed generally. The decision of the Court, in most cases, can affect only the parties before it. Whether others read and heed it is another matter.

At the outset, it may be said with confidence that very little is in fact known about the actual societal impact of judicial decisions, or, put another way, about the causal connection between social change and judicial action. ${ }^{33}$ There has been much loose talk about such a connection, but the studies are well-nigh non-existent, save for the church-state relationship problem where some political scientists have made studies. ${ }^{34}$ Much has been made about the allegedly

\footnotetext{
82 See Note, 67 HARv. L. REv. 1251 (1954); Note, 56 YALE L.J. 574 (1947).

${ }^{88}$ See Miller, On the Need for "Impact Analysis" of Supreme Court Decisions, 53 GEO. L.J. 365 (1965).

st E.g., Beaney \& Beiser, Prayer and Politics: The Impact of Engel and Schempp on the Political Process, 13 J. Pub. L. 475 (1964).
} 
key role the Supreme Court has played in American history; and as recently as the 1930s "government by judiciary" could seriously be suggested. ${ }^{35}$ Would the nation be different today had Marbury ${ }^{36}$ and McCulloch, ${ }^{37}$ Gibbons $^{38}$ and Cooley, ${ }^{39}$ Missouri v. Holland ${ }^{40}$ and Nebbia v. New York, ${ }^{41}$ Jones \& Laughlin ${ }^{42}$ and Steward Machine, ${ }^{43}$ Darby $^{44}$ and Wickard, $9^{45}$ Shelley ${ }^{46}$ and Brown, ${ }^{47}$ Baker ${ }^{48}$ and Reynolds, ${ }^{49}$ been decided differently-or had not been decided by the Supreme Court at all? Suppose the social problems inherent in those judicial decisions had been decided politically, as they would have in other democratic nations, would the net result be fundamentally different?

In many respects the question is idle and impossible to answer. The Court did exist and did make decisions; the nation has changed from situation $A$ in 1787 to situation $B$ in 1967. However, it seems clear that historians simply cannot supply an answer to such a question. In another sense, it of course is commonly assumed that the fact of the Court's acting as ultimate constitutional interpreter has made a difference. John $R$. Commons could call it "the first authoritative faculty of political economy in the world's history." Boudin and others maintained that this made ours a "government by judiciary"; a president of the American Bar Association asserted as recently as 1962 that fundamental changes are being wrought in the fabric of government by the Court, ${ }^{51}$ a view echoed by Justice John M. Harlan. ${ }^{52}$ Many others, in and out of the law, have made similar pronouncements. Even the cool-minded Holmes, who saw

\footnotetext{
${ }^{85}$ BOUdIN, GOVERNMENT BY JUdICIARY (1932).

${ }^{86}$ Marbury v. Madison, 5 U.S. (1 Cranch) 137 (1803).

${ }^{37}$ McCulloch v. Maryland, 17 U.S. (4 Wheat.) 316 (1819).

${ }^{88}$ Gibbons v. Ogden, 22 U.S. (9 Wheat.) 1 (1824).

${ }^{30}$ Cooley v. Board of Wardens of Philadelphia, 53 U.S. (12 How.) 299 (1851).

10252 U.S. 416 (1920).

4291 U.S. 502 (1934).

42 NLRB v. Jones \& Laughlin Steel Corp., 301 U.S. 1 (1937).

4s Steward Mach. Co. v. Davis, 301 U.S. 548 (1937).

* United States v. Darby, 312 U.S. 100 (1941).

16 Wickard v. Filburn, 317 U.S. 111 (1942).

to Shelley v. Kraemer, 334 U.S. 1 (1948).

47 Brown v. Board of Educ., 349 U.S. 294 (1955).

18 Baker v. Carr, 369 U.S. 186 (1962).

to Reynolds v. Sims, 377 U.S. 533 (1964).

50. Commons, legal Foundations of Capitalism 7 (1924).

${ }^{51}$ See Satterfield, President's Page, 48 A.B.A.J. 595 (1962).

${ }^{52}$ See Reynolds v: Sims, 377 -U.S. 533, 624 (1964) (Harlan, J., dissenting). See also Norman v. Baltimore \& O.R.R., 294 U.S. 240, 381 (1934) (McReynolds, J., dissenting).
} 
things whole and who was not likely to be deluded by images of judicial grandeur, could say that the Court has made a great difference in the nature of federalism-even though he asserted that little difference would result if the Court lost its power to declare acts of Congress and the Executive unconstitutional.

Against that array of talent, one would be temerarious indeed to suggest a contrary view. The essential question involves the relationship between legal and social change; here the most that can be said is that we simply do not know the impact the Supreme Court has had on the structure and nature of American society. No empirical data exists to show a causal connection. What is available are the ipse dixits of a number of observers. The Court, accordingly, may have made a difference, but no one can tell precisely what that difference is. It will not do, in other words, to make grand pronouncements like Professor Felix Frankfurter, who said in 1938:

We speak of the Court as though it were an abstraction. To be sure the Court is an institution, but individuals, with all their diversities of endowment, experience, and outlook, determine its actions. The history of the Supreme Court is not the history of an abstraction, but the analysis of individuals acting as a Court who make decisions and lay down doctrines, and of other individuals, their successors, who refine, modify, and sometimes even overrule the decisions of their predecessors, reinterpreting and transmuting their doctrines. In law also men make a difference. It would deny all meaning to history to believe that the course of events would have been the same if Thomas Jefferson had had the naming of Spencer Roane to the place to which John Adams called John Marshall, or if Roscoe Conkling rather than Morrison R. Waite had headed the Court before which came the Granger legislation. The evolution of finance capital in the United States, and therefore of American history after the Reconstruction period, would hardly have been the same if the views of men like Mr. Justice Miller and Mr. Justice Harlan had dominated the decisions of the Court from the Civil War to Theodore Roosevelt's administration. There is no inevitability in history except as men make it.53

The difficulty with this statement is at least two-fold: first, it reveals a philosophy of history which itself is in dispute. ${ }^{54}$ Men make a

\footnotetext{
68 Frankfurter, Law and Politics 62 (1939).

* See Frank, Fate and Freedom (1945).
} 
difference, says Professor Frankfurter, but how does he know? Here, again, is another example of the intuitionist fallacy: Why, one is forced to ask, is there any solid basis for believing that "men make a difference?"

Whatever conclusion one draws on the "inevitability in history ... as men make it," historical interpretation, it seems clear, is bound up with value judgments: "the search for causalities in history is impossible without reference to values [for] . . . behind the search for causalities there always lies, directly or indirectly, the search for values." ${ }^{56}$ Furthermore, when we view the past and attempt to achieve an understanding of it, it can only be through the eyes of the present. The historian is unavoidably a product of the age in which he lives and is bound to it by the conditions of human existence. Even the words he uses-words like democracy or capitalism or property-have present-day connotations from which he cannot divorce them. Finally, causation itself as a legal concept is complex and difficult. Whether it is in the context of the present inquiry of the relationship between judicial decision and social change or in such matters as establishing tort liability, legal causation is far different from causation in the laboratory, where within rigidly limited circumstances a natural scientist can "cause" certain results through the operation of known, invariable "natural" laws.

However, adapting the scientific method to the problem of causality in human affairs in order to support assertions is a most difficult task, perhaps ultimately impossible. "The craving for an interpretation of history is so deep-rooted that, unless we have a constructive outlook over the past, we are drawn either to mysticism or to cynicism." 57 In present context, the Frankfurter position tends toward mysticism; to be able to avoid cynicism, it seems to be necessary to have available, at the very least, deep and continuing studies into the manner in which the American people "obey" Supreme Court edicts. Without such studies, one can give meaning to history if he so chooses, but what he is stating will tend to be merely a re-

s5 "How can one discover in history a coherent sequence of cause and effect, how can we find any meaning in history, when our sequence is liable to be broken or deflected at any moment by some other, and from our point of view irrelevant, sequence?" CARR, WHAT is History? 130 (1962).

${ }^{\circ}$ Quoted in id. at 141. See Miller \& Howell, The Myth of Neutrality in Constitutional Adjudication, 27 U. CHr. L. REv. 661 (1960).'

${ }^{57}$ Quoted in CARR, op. cit. supra note 55, at 144. 
flection of his personal valuations. One sees meaning-or historical causation-where one wants to see it.

But we should not be optimistic that such studies will be made. Legal scholars, whether lawyers or political scientists or others who have singled out the Supreme Court for scrutiny, have been anything but quick to produce the necessary data. One searches the literature in vain for anything more than sporadic forays into the uncharted sea of "impact analysis." 58 In the main, such studies have been in the area of the influence Court decisions have had on the churchstate relationship. Although these, too, are far from definitive, one may conclude from them that the Court's pronouncements have had at best a highly discontinuous impact; in some areas, they have been obeyed, in others, ignored. When one adds to this the concomitant fact that, at the very time that the Supreme Court was uttering the decisions about walls high and impregnable between church and state, the federal government was entering into systematic subsidization of church-related (as well as other) schools, one wonders just what the Supreme Court's power is. ${ }^{59}$ It seems small indeed.

On the other hand, how does one explain the well-nigh unanimous acceptance of Baker $v$. Carr 60 and its progeny? There can be no question here that the Court has wrought significant changes in the composition of state legislatures and the House of Representatives. However, when one compares the public reaction to that series of cases with that which followed Brown $v$. Board of Education, ${ }^{61}$

"See Miller, On the Need for "Impact Analysis" of Supreme Court Decisions, 53 GEo. L.J. 365 (1965). Professor Walter Murphy has stated flatly: "No serious student of public law has ever doubted the immense power of the Justices ...." Murphy, Deeds Under a Doctrine: Civil Liberties in the 1963 Term, 59 AM. Pox. Scr. Rev. 64, 75 (1965). We doubt the validity of Murphy's statement insofar as the power of the Court is concerned; at best, we simply do not know just what the power of the Justices is, has been, or will be. Perhaps, as Whitehead once said, "the doctrines which best repay critical examination are those which for the longest period have remained unquestioned." WhItEHEAD, Adventures of IDEAs 228 (1933). Judicial power is one of those doctrines. For further discussion, compare Dahl, Decision-Making in a Democracy: The Supreme Court as National Policy-Maker, 6 J. PuB. L. 279 (1957), with Levy, Judicial Review, History and Democracy: An Introduction, in Jubictal Revew and tHe Suprenie Court 1 (Levy ed. 1967). See also Commager, Majority Rule aND MINORITY RIGHTS (1943).

50 See S. 2097, 89th Cong., 2d Sess. (1966), introduced by Senator Sam Ervin of North Carolina, which would seek to require the Supreme Court to decide the validity of disbursements to church-related schools. See Hearings Before the Subcommittee on Constitutional Rights of the Senate Judiciary Committee, 89th Cong., 2d Sess., pts. I-2 (1966).

oo 369 U.S. 186 (1962).

Q1 349 U.S. 294 (1954). 
he is forced to the conclusion that the pattern of adherence to judicial prescription is uneven. Even on reapportionment, moreover, we do not know with any certainty just what the ultimate impact will be, for there have been few if any studies made to determine whether different legislative decisions will result after reapportionment, as compared with the different identity of the legislators. ${ }^{.2}$

Whether one can explain the discontinuous reception given Supreme Court decisions is the question. Can it be on any other basis than that decisions are "obeyed" when they are in consonance with the deep-felt preferences of the people? No other equally tenable suggestion seems available. Historically speaking, furthermore, it is difficult, perhaps impossible, over the nearly two centuries of Supreme Court history to find one instance where the Court has been able to do more than postpone what a determined people or legislative majorities wanted. It may well be that at times the Court helped the people to know what they wanted-by articulating the "national conscience" ${ }^{33}$-and thus had influence. ${ }^{\text {of }}$ But this is a far cry from saying that it caused constitutional or social change. The second tentative hypothesis, accordingly, appears to have validity.

\section{$A$ Third Hypothesis}

Our third hypothesis complements the first two: The Supreme Court has power to the extent to which the avowedly political branches of government-Congress, the President, the state governments-affirmatively respond to the norm announced by the Court.

ane might hypothesize that legislative decisions, whether on the state or national level, are the resultant of a parallelogram of conflicting group forces and that, accordingly, a rural-urban dichotomy would be far too simplistic if it were taken to mean that because legislatures are now made up of more representatives from urban areas the ultimate decisions will be different than they would have been if rural America had retained control. See McConnell, Private Power and American Democracy 91-118 (1966); Truman, The Governmental Process 213-391 (1951); Ziegler, INTEREST Groups IN AMIERICAN SOCIETX (1964).

is We make no statements regarding the manner in which the Justices do or should ascertain the "national conscience."

os Speaking very broadly, one may discern three functions of the Supreme Court: (1) validating constitutional change and thereby updating the Constitution, see Miller, Notes on the Concept of the "Living" Constitution, 31 GEo. WASH. L. REv. 881 (1963); (2) interpreting statutes, particularly in socio-economic areas, see Miller, Constitutional Revolution Consolidated: The Rise of the Positive State, 35 GEO. WASH. L. REv. 172 (1966); (3) norm-setting or acting as the national conscience, see Cox, Foreword, Constitutional Adjudication and the Promotion of Human Rights, 80 HARv. L. REv. 91 (1966); Miller, An Affirmative Thrust to Due Process of Law?, 30 Geo. Wash. L. REv. 399 (1962). 
Defiance of a judicial edict is far from unknown; but even more familiar is indifference to what a court has said. The judicial command runs to the parties only and binds only them; anyone not before the bar of the court can with impunity ignore the decision and await the application of the principle or rule there enunciated to him in a proper case. This is the nub of the problem: a Supreme Court decision in a constitutional matter states the law of the case and not the law of the land, as is often asserted. Judges are inherently limited by their inability to articulate general norms. Their creativity is not only confined "from molar to molecular motion"; in final analysis it can affect only the particular interests of the litigants then before it-unless and until others, without direct command and without possibility of sanction, are willing to abide by it. And this observation is valid even though it may be clearly predictable that the Court and lower courts will decide the same way in a similar future case. Legislative commands, on the other hand, are general; they affect all in similar circumstances.

The difference, while technical, is important: one does not violate the rule in, say Brown v. Board of Education, unless and until someone within the jurisdiction in question brings an action with similar facts; but one does violate Title VI, say, of the Civil Rights Act of 1964 by not adhering to the legislative and administrative commands. The law enunciated by the Supreme Court in Brown, was the "law of the land" only because one could, by following the prediction theory of law, forecast the same result should other cases be brought. Not so, however, with the general congressional norms, even though subsequent determinations have to be made that violations in fact occurred. There has been much loose talk in recent years about a Court decision stating the "law of the land," but the talk is just that -loose. No matter how much one approves certain results, the commands of the judiciary are aimed only at those before the court except, of course, in the case of a class action (or in the Supreme Court's supervisory power over lower federal courts) ${ }^{65}$ This is un-

${ }^{\circ 5}$ On class actions, see Note, 71 HARv. L. REv. 874, 928-43 (1958). See newly amended FED. R. Crv. P. 23 and Notes of the Advisory Committee thereon. As will be developed in Part Two, the function of the litigant in constitutional litigation is solely that of getting the case to the Court. Once that is performed, he largely becomes irrelevant, even though the decision will affect him directly. The pronouncement of the Court, furthermore, is limited to the litigants; and that is true even though the Court, as Mr. Justice Harlan has said, chooses its cases "in the interests of the law, 
fortunate for those who applaud the recent activism of the Supreme Court, but true it is, nonetheless. On the other hand, it is in accord with the wishes of those who advocate a quietistic role for the Court. ${ }^{86}$

A Supreme Court pronouncement in a constitutional case in effect delegates authority to others-legislatures, executives, administrators, and judges in lower courts (federal and state)-to carry out the terms of the edict in other situations. Other than judges in lower federal courts, whether they do so is required neither by the Constitution nor the Court decision; nor is it a requirement of statutes, discretion in the delegate being the rule. ${ }^{67}$ It depends, ultimately, upon the willingness of those who occupy positions in the political branches of government to recognize the Court decision and to follow it up with official action. ${ }^{88}$ Whether they do so seems to be a resultant of

its appropriate exposition and enforcement, not in the mere interest of the litigants." Harlan, Manning the Dikes, 13 RECoRd of N.Y.C.B.A. 541, 551 (1958).

On the supervisory power over the federal courts, compare Cheff v. Schnackenberg, 384 U.S. 373 (1966), with Green v. United States, 356 U.S. 165 (1958). In this area, the Court's "legislative power" is at its peak.

os Compare Bickel, The least Dangerous Branch; The Supreme Court at the Bar of Polttics (1962).

Of course, a decision can have an immediate wide influence, as witness the aftermath of Baker $v$. Carr. And a cumulative effect may be seen in a series of decisions, as in racial segregation, which in total impact tends toward a general norm. Furthermore, the Court in such cases as Miranda v. Arizona, 384 U.S. 436 (1966), has announced detailed guidelines in certain aspects of criminal law administration, a decision which is at once a form of "advisory opinion" and an apparent attempt to legislate "a detailed set of operational procedures." See Schwartz, Retroactivity, Reliability, and Due Process: A Reply to Professor Mishkin, 33 U. CH. L. Rev. 719, 758 (1966). The ultimate impact of Miranda and its companion, Johnson v. New Jerscy, 384 U.S. 719 (1966), is yet to be determined.

${ }_{87}$ For an assertion that ours is emphatically "a government of men, not of laws," see HORSKY, THE WASHINGTON LAWYER 68 (1952). In other words, there is a large element of discretion within the public administration. See 1 Davis, Administrative LAW TREATISE $\S 4.16$ (1958, Supp. 1965). And what is true of the public administration is a fortiori valid for the legislatures.

An instructive insight into the power of the Court, particularly as it relates to the public administration and to lower federal courts, may be found in a case decided after the text was written, Cascade Natural Gas Corp. v. El Paso Natural Gas Co., 87 Sup. Ct. 932 (1967). In that decision, the Court, after finding that the Antitrust Division of the Department of Justice had "knuckled under" to one of the litigants, went to the extraordinary lengtl of ordering the removal of the federal district judge from further participation in the case.

${ }^{8}$ Whether official action is forthcoming would seem in turn to depend, at least in part, upon the extent to which interest groups within American society can bring influence to bear upon the political processes. See authorities cited in note 61 supra. Other factors may, of course, bear upon what is done politically following a Supreme Court decision; we make no attempt to indicate liere what they may be, but mexely 
political factors, rather than legal commands: the difference between President Jackson's (perhaps apocryphal) sneer at Chief Justice Marshall's decision and President Eisenhower's use of armed forces in Little Rock in 1957 reveals the uncertainties of the process. Here, as elsewhere, Bishop Hoadly's dictum is apposite: he who has the power to interpret the law is more truly the lawmaker than he who originally states the norm.

The racial segregation situation again provides illustration. Despite such decisions as Cooper v. Aaron ${ }^{69}$ and Bailey v. Patterson, ${ }^{70}$ cases in which the Court tried to establish a general norm, segregation, de facto or de jure, is still a "litigable issue." The tribulations experienced in the administration of Title VI of the Civil Rights Act of 1964 are ample evidence of that. In the field of administrative law, other evidence exists. For example, several years after the Phillips decision of the Court in 1954, the Federal Power Commission had still not adhered to it. ${ }^{71}$ For that matter, it is by no means clear that the President, as a constitutional matter, must follow congressional commands, as the history of presidential impounding of appropriated funds indicates. ${ }^{22}$ Furthermore, the commands issued by the Court are not necessarily "followed" by lower courts, as Professor Walter F. Murphy has shown ${ }^{73}$ and as the following episode evidences:

Walton Hamilton tells the story of the effectiveness of Tumey v. Ohio, 273 U.S. 510 .... When he was caught in some "speed trap" in Pennsylvania and taken before a justice of the peace, he asked the J.P. how much of the fine the J.P. got. When the reply "five dollars" was forthcoming, Mr. Hamilton mentioned that this was

point out that political recognition of judicial decisions is not automatic, an obvious fact of which little is known.

e9 358 U.S. 1 (1958).

${ }^{70} 369$ U.S. 31 (1962). In the Bailey case, the Court expressly stated: "We have settled beyond question that no state may require racial segregation of interstate or intrastate transportation facilities. ... The question is no longer open; it is foreclosed as a litigable issue." Id. at 33.

${ }^{71}$ Phillips Petroleum Co. v. Wisconsin, 347 U.S. 672 (1954), referred to by James M. Landis in Hearings of the Subcommittee on Administrative Practice and Procedure of the Senate Committee on the Judiciary, 86th Cong., 2d Sess. 316 (1960).

${ }^{72}$ See Miller, Presidential Power to Impound Appropriated Funds: An Exercise in Constitutional Decision-Making, 43 N.C.L. REv. 502 (1965). The congressional remedy in such instances seems solely that of impeachment. See also Berger, Executive Privilege v. Congressional Inquiry, 12 U.C.L.A.L. REv. 1043, $1111-17$ (1965).

${ }^{23}$ Murphy, Lower Court Checks on Supreme Court Power, 53 AM. POL. ScI. REv. 1017 (1959). 
unconstitutional. "Who said that?" he was asked. Upon learning that it was the United States Supreme Court, the J.P. shrugged and said, "Oh well, I didn't think it was any Pennsylvania court."74

Anyone who has been caught in a speed trap in Georgia in recent years knows that this is not an isolated incident. As Professor George Braden phrased the matter, "We do not know how effective a Supreme Court decision is, or in what manner its effect is transmitted."75 Those who, in the American framework of government, must or should listen to the commands of the Court, may choose to follow them or not depending upon whether it is politically or philosophically palatable to do so. Certainly little or nothing is known about the manner in which official behavior follows judicial edict $^{76}$-and official behavior is what is important, for it is still by and large true that the Constitution runs against governments only. The behavioral patterns of persons, both natural and artificial, are little concerned with judicial norms-excluding, of course, the litigant (s) before the Court in a specific case. ${ }^{77}$

The requirement for an affirmative response to a Supreme Court decision prompts the further question: To what extent, if at all, is there is a constitutional duty on the part of government (or its officials) to take action? Some recent decisions of the United States Supreme Court and of the California Supreme Court suggest that a concept of constitutional duty may be in process of "becoming." Even though the notion is as yet inchoate, it is nevertheless possible to read such decisions as Burton $v$. Wilmington Parking Authority, ${ }^{78}$ United States v. Guest, ${ }^{79}$ Katzenbach v. Morgan, ${ }^{80}$ Evans v. Newton, ${ }^{81}$ Griffin v. School Board, ${ }^{82}$ and Mulkey v. Reitman ${ }^{83}$ as at least imply-

\footnotetext{
"Braden, Legal Research: $A$ Variation on an Old Lament, 5 J. LEGaL ED. 39, 41 $\mathrm{n.1}$ (1952).

70 Ibid.

7o Such ignorance prevails even in the area of administrative law. Sce Miller, Book Revicw (of Jaffe, Judiclal Contror of Administrative Action), 34 Geo. Wash. L. REV. 970 (1966).

77 For example, a survey in 1964 found that most school districts in Kentucky had not adhered to the Court's prayer decisions. See N.Y. Times, Aug. 30, 1964, § 1, p. 70, col. 5 .

${ }^{78} 365$ U.S. 715 (1961).

78383 U.S. 745 (1966).

${ }^{80} 384$ U.S. 641 (1966).

81382 U.S. 296 (1966).

82377 U.S. 218 (1964).

8s 50 Cal. 2d 881, 413 P.2d 825 (1966). See Cox, supra note 64; Miller, An Affirmative Thrust to Due Process of Law?, 30 Geo. WASH. L. Rev. 399 (1962).
} 
ing that, if at any time a state could prevent racial discrimination, its failure to do so is state action. That proposition, stated in more positive terms, means that the fourteenth amendment imposes a duty upon states to take action to prevent racial discrimination. Under the principle of Bolling $v$. Sharpe, ${ }^{84}$ a like duty would then be imposed in areas of racial discrimination upon the federal government. In other words, the Constitution not only carries negative prohibitions; freedom is as much positive as negative. ${ }^{85}$

In recent decades it has become clear beyond peradventure that a massive realignment of function has been taking place within each of the three branches of government set up by the Constitution. The most basic alteration, perhaps, is the rise of the "administrative state"-the Positive State-headed by a presidency ever growing in power. Accomplished through the medium of delegations from Congress, the public administration now does and increasingly will represent the real power center of government. A consequence has been a diminution in relative power of Congress ${ }^{88}$ and also a lessening in the power of the United States Supreme Court, particularly over economic policy questions. The principal implications of the new alignment of function and power will be more fully discussed in Part Two; suffice it now to say that it has become apparent in the new adjustment of roles that the three branches must of necessity cooperate more than compete: "Government in the Positive State means that the separation of powers, which historically has helped to protect liberty through the inevitable frictions brought about by the 'checks and balances,' cannot be permitted to stymie the reasonable realization of the aims of the people of that State."87 The suggestion here is that a concept of constitutional duty on the part of government, and thus of governmental officials, is now being created as a serendipitous by-product of some of the recent decisions of the

\footnotetext{
84347 U.S. 497 (1954).

85 "For an individual to have freedom to participate and to attain the goals imbedded in the concept of human dignity, it is necessary that he have freedom from both the arbitrary exercise of power and the inadequate social conditions which make it improbable that he can achieve that plane. The social basis of liberty, in the sense that affirmative duties are imposed on the State, has thus far received relatively little attention from constitutional scholars ..." Miller, An Affirmative Thrust to Due Process of Law?, 30 Geo. WASH. L. Rev. 399, 425 (1962). (Emphasis in original.)

${ }^{80}$ See the several essays collected in The Congress AND AMErICA's Future (Truman ed. 1965).

${ }^{87}$ Miller, An Affirmative Thrust to Due Process of Law?, 30 GEo. WASH. L. REv. 399, 427 (1962).
} 
United States Supreme Court and other courts. In the language of the Declaration of Delhi, made in 1959 by the International Congress of Jurists:

The International Congress of Jurists ...

....

Recognizes that the Rule of Law is a dynamic concept for the expansion and fulfillment of which jurists are primarily responsible and which should be employed not only to safegnard and advance the civil and political rights of the individual in a free society, but also to establish social, economic, educational and cultural conditions under which his legitimate aspirations and dignity may be realized. ...88

However, it is one thing to say that an abstract official duty to take action may exist, but quite another to determine who may be able to enforce it. In some few cases a proper plaintiff has been located and permitted to bring-and to win-actions designed to enforce such a duty. The prime example, perhaps, is the Prince Edward County case, ${ }^{89}$ although surely Baker $v$. Carr $^{90}$ and its prog. eny would also indicate that the problem is not an insuperable one (assuming, of course, that one agrees that Baker is in its effects the enunciation of a duty to reapportion). However the inchoate notion of constitutional duty is resolved, the inability of the Supreme Court to do much more than issue grand pronouncements and then hope for acquiescence places a great responsibility upon the officials of the avowedly political organs of government, both federal and state. The Court articulates the ideals of the American democracy, but those ideals can become hollow if not followed by affirmative response by the other governmental officials. Whether they are does not depend upon judicial adherence to the declaratory theory, or even in making reasoned, principled decisions. ${ }^{21}$ It would seem, thus, that the third tentative hypothesis advanced has considerable validity.

\footnotetext{
${ }^{8}$ INTERnational Congress of JURtsts, The RuLe of Law in a Free SOciety 3 (1960). See Thorson, $A$ New Concept of the Rule of Law, 38 CAN. B. REv. 239 (1960). For a discussion of the affirmative obligations of government, see Ackley, Foreword: The Employment Act After Twenty Years: The Legal Basis for Managing the Economy, 35 GEO. WASH. L. REv. 170 (1966).

so 377 U.S. 218 (1964). See United States v. Jefferson County Bd. of Educ., Civil No. 23345, 5th Cir., Mar. 29, 1967 (affirmative duty of states to effect school integration). ${ }^{\circ 0} 369$ U.S 186 (1962).

${ }^{21}$ But see Edelman, The Symbolic Uses of Politics 32, 108 (1964).
} 
In SUMmation

We have suggested three hypotheses concerning the power of the United States Supreme Court. Each would require much study and empirical data to be validated. Even so, each seems to be tenable as a working hypothesis. And each offers a way of more significant thinking about the Court than the intuitive propositions usually advanced, propositions which are largely based upon nothing more than reading of Supreme Court opinions. What conclusions, if any, may be drawn from such an analysis?

That question will be developed in Part Two. At present, we summarize some of the implications of the foregoing investigation. The first is to suggest one painfully obvious inference: Using the texts of judicial opinions as the sole source of data concerning the Court, its operation, and its power, simply will not suffice to provide the minimal informational needs upon which to base conclusions. Although, as Professor Ernest J. Brown said in the course of discussing a Supreme Court opinion, we "cannot explore the minds of Justices, and what they do not put on paper we do not know,"92 what they do put on paper in their published opinions is not enough to answer the critical questions. All that such verbiage does is to permit the scholarly disputation with which we are all familiar but which does not lend true understanding or clarity to the judicial process. "The fact is," in the words of Felix Frankfurter, "that pitifully little of significance has been contributed by judges regarding the nature of their endeavor ...." "93

It follows that legal training alone is of little help, for most of it is still concerned with analysis of appellate court opinions; as for constitutional law, analysis of Supreme Court opinions is almost the entire scrutiny. Those opinions being at best poor vehicles, data must perforce be produced from outside of the traditional confines of the legal profession. One should not be sanguine on that score, for little of significance has thus far been produced. ${ }^{94}$ Some intel-

\footnotetext{
${ }^{02}$ Brown, Quis Custodiet Ipsos Custodes?-The School-Prayer Cases, 1963 Sup. Cr. REv. 1, 32.

${ }^{03}$ FRANKFURTER, OF LAw AND MEN 32 (1956). He went on to say: " and, I might add, that which is written by those who are not judges is too often a confident caricature rather than a seer's version of the judicial process of the Supreme Court." Ibid.

o\& Little has been added to our knowledge of the nature of the judicial process since Holmes published The Common LAW in 1881 or Cardozo his The Nature of the Judiclal Process in 1921.
} 
lectual stirrings, however, are visible and should eventually add to our knowledge about the high tribunal. ${ }^{95}$ Questions such as the following must be asked and answered:

Much of the commentary about the Supreme Court ... does not pose the proper questions. Few, perhaps none, of those who participate in today's debate about the Court reach the tough problems. ... The time has come [to make] . . . concerted effort to analyze the Court as dispassionately as possible. Such questions as the following [are] ... in need of development: (1) the data relevant to the decisional process; (2) impact analysis of Court decisions; what difference does a decision make in the practices of the American people? (3) what are the factors which have influenced the Court? (4) what are the preferred means of getting information to the Court? (5) are there aids that could be established through which the Court could receive assistance in making decisions? (6) what are the "social realities" which the Court should consider? (7) what are the goals which the Court does, and should, seek? (8) what is the relationship-and what should it beof the Court to other units of government? (9) what insights can students of the sociology of knowledge and of human cognition bring to an understanding of the thought processes of the Justices? and (10) what are the criteria (principles) which should operate as standards of judgment by the Justices (and of evaluation of the Court's work by commentators) ? $^{\text {ge }}$

Of course, some of the commentary about the Court has dealt at least in part with certain of these questions. For the most part, however, they remain unanswered. As a result, our knowledge about law and legal institutions, including the Supreme Court, is roughly comparable to that in the natural sciences of 100 to 150 years ago, before scientific knowledge was revolutionized by Darwin and Mendel, by Planck and Einstein, and the others who precipitated the scientific revolution. Law and lawyers are in a pre-Darwinian stage, perhaps even in a pre-Newtonian and pre-Copernican stage. ${ }^{97}$ As yet, there is not even an accepted taxonomy. While doctrinal analysis is

\footnotetext{
${ }^{0 r}$ Most of these studies tend to be by political scientists, rather than lawyers (practicing or academic). A study of the reasons for the paucity of instructive and illuminating studies of the judicial process, particularly by the legal profession, would itself make a valuable contribution.

${ }^{\circ}$ Miller, Book Review (of Bickel, The Least Dangerous Branch), 9 Hownad L.J. 188,190 (1963).

${ }^{\circ 7}$ See Miller, Public Law and the Obsolescence of the Lawyer, - U. FLA. L. REV. (1967).
} 
necessary and should be continued, it alone cannot give us an adequate understanding of the Court. ${ }^{88}$

A third point underscores what has been said previously: there is a need for hard factual data about the attitudes and preferences of the American people toward the Supreme Court. It will not do to make a priori pronouncements about the symbolic role of the High Bench unless and until we actually know that the American people give any thought to (I) the Court itself or (2) its methodology. On this, our knowledge is almost completely lacking. ${ }^{99}$

Implicit in the three hypotheses set forth above is the idea that the Court must innovate, that is, that it must routinely face the rigors of the "sovereign prerogative of choice" in making decisions. This, as Arnold Toynbee has recently stated, is the principal way in which human affairs, including law (although he did not mention law), are to be distinguished from scientific pursuits: "What element is it in human affairs that makes impossible ... the exact mathematical prediction that is so brilliantly successful in our calculations about nonhuman nature? Evidently our unknown quality in the realm of human affairs is a human being's apparent power of making

${ }^{98}$ Perhaps some of the gaps in our knowledge about the law and the legal process, as compared with knowledge of rules and doctrines, may be traced to the failure of undergraduate colleges to include the requisite courses in their curricula. Jurisprudence in the sense of knowledge about how law operates in the social system should be part of the prescribed education of all undergraduates; no one can be said to have a liberal education without it. Compare'Barkman, Law-in-the-Liberal Arts: An Appraisal and $A$ Proposal for Experimentation, $19 \mathrm{~J}$. LEGAL ED. 1 (1966).

${ }^{\circ}$ One study of courts in Wisconsin which is of relevance here concludes: "Public acquiescence to judicial actions in the realm of policy-making hardly seems to be $a$ function of the 'priestly' image promulgated by Lerner and Frank; neither is it a function of the "Blackstonian" image proclaimed by Mishkin and Arnold. In the face of widespread disagreement with the substance of judicial innovations in public policy areas, public support seems a matter more of acquiescence or ignorance rather than positive endorsement, and of respect for the judiciary as one kind of government official rather than as a distinctive office embodying unique functions and status. Indeed, in our interviews judges were typically respected as dignified representatives of the people and the state, as men of distinguished achievement, rarely as aloof guardians of immutable, constitutional principles." Ladinsky \& Silver, Popular Democracy and Judicial Independence: Electorate and Elite Reactions to Two Wisconsin Supreme Court Elections, 1967 WIS. L. REv. -.

This study, buttressed by a few others, of course actually "proves" little or nothing about the United States Supreme Court. What it does indicate, at least in part, is that untested assumptions and pronouncements about the Court will not suffice, insofar- as they relate to the attitudes and preferences of the American people. Empirical information must first be obtained. This does not mean that the Court need change its methodology, but merely that commentary upon the Court should transcend the doctrinal exegeses now so prevalent. See Miller, On the Need for "Impact Analysis" of Supreme Court Decisions, 53 GEo. L.J. 365 (1965). 
choices." 100 And choices inevitably involve, insofar as law is concerned, something quite different from the declaratory theory of law. That theory is based upon the proposition that there is but one "true" principle or rule to be applied in a given factual situation. The entire history of the adversary system is impressive testimony to the contrary, at least with respect to appellate litigation (which, of course, is the great bulk of the Supreme Court's work). Put another way, the adversary system in appellate courts requires choices by judges, choices which inevitably mean that innovation must take place..$^{01}$

Fifth, it is of vital importance in any analysis of the Supreme Court today that it be seen as a part of government quite different from that contemplated in 1787, a government which exists in a society wholly different from that of the late 18th century. The declaratory theory of law is a product of a pre-industrial age, of an agricultural, even feudal, society. The United States today, preeminent in wealth and power, straddles the continent and knows no earthly frontiers so far as public policy is concerned. This, then, means the proliferation and dominance of public law, rather than the private law of pre-Civil War times. In legal systems which are private-law oriented and which exist in an essentally static society, one can think of law in terms of a closed system of concepts. Not so, however, with a public-law dominated system, existing in an age of constant and even cataclysmic change: the requirement is to look upon law as "process"-for the ends to be achieved, for the goals to be sought. The industrial revolution, Herbert Rosinski has said, has transformed man's way of life "from an 'existence' into an unending 'process." "102 Public law is an unending process, an endless succession of partial solutions to public policy questions. The legal profession has not yet come to terms with the growth and domination of public law, but this must be done if ever an adequate theoretical formulation of law in the modern era is to be produced.103

Constitutional law, in the sixth place, is a flow of decisionsjudicial, legislative, and executive-and also of certain habits and

100 Toynbee, Change and Habit 5 (1966).

${ }^{101}$ See Miller, On the Choice of Major Premises in Supreme Court Opinions, 14 J. PUB. L. 251 (1965).

102 ROSINSKI, POWER ANd Human DEstiny 93 (1965).

${ }^{108}$ See generally Miller, Public Law and the Obsolescence of the Lawyer, - U. FLA. L. REV. - (1967). 
patterns of behavior which can be given the label of custom. Open ended, it is always in a state of "becoming." The fiction of the declaratory theory clouds truth and does not enable the Court to receive the assistance that it needs if it is to continue to perform its high functions. Thurman Arnold to the contrary notwithstanding, ${ }^{104}$ briefs cannot be written before the Court on any other theory than that the Justices have choices to make between competing rules or principles of equal persuasiveness (provided, of course, that the case is not a frivolous one). But whether the members of the Court will want to be open in decribing their decision-making is quite another matter; quite possibly, they will not privately face up to the discretion they have. ${ }^{105}$ Some judges may wish to proceed "by denying change"108-the time-honored way of common-law judges. As Holmes said in 1897 ,

I think that the judges themselves have failed adequately to recognize their duty of weighing considerations of social advantage. The duty is inevitable, and the result of the often proclaimed judicial aversion to deal with such considerations is simply to leave the very ground and foundation of judgments inarticulate, and often unconscious .... ${ }^{107}$

But weighing considerations of social advantage is what legislators are supposed to do. ${ }^{108}$

\footnotetext{
${ }^{104}$ See note 113 infra and accompanying text.

108 See Frank, LAW and the Modern Mind 32-41 (1930); ShkLar, LegalisM 101 (1964).

${ }^{100}$ See Diesing, REAson in SOcIETY 154 (1962).

${ }^{207}$ Holmes, The Path of the Law, 10 Harv. L. REv. 457, 467 (1897). He went on to say: "I cannot but believe that if the training of lawyers led them habitually to consider more definitely and explicitly the social advantage on which the rule they lay down must be justified, they sometimes would hesitate where now they are confident, and see that really they were taking sides upon debatable and often burning questions." Id. at 468.

${ }^{108}$ Dr. Judith Shklar put the matter in effective focus in her recent book: "All judges must sooner or later legislate-create rules either unconsciously or openly. The codes of several European countries directly provide for this possibility, and in the United States it is an accepted aspect of every stage of judicial activity. From Austin to Gray, moreover, writers on jurisprudence have urged judges to face the facts of life candidly, to accept the responsibilities the community has placed upon their shoulders, and to make rules that seem to them useful and intelligent. To the judge, however, these are frightful occasions. By training and professional ideology he is tied to a vision of his function that excludes self-assertion and places a premium on following existing rules impartially. His natural impulse is to find a rule at any cost, or at least to assimilate his decision to a rule as closely as possible. He may even openly evade responsibility .... [I]t is obviously of great importance to him that the rules he relies on be based on universal agreement among either the experts, the wise, or the
} 
Finally, truth is to be valued for itself alone, even though it may "lie at the bottom of a well." However subversive of the established order it may be, truth is an ultimate value. As a nation, we are deeply committed to it; thoughtful citizens become disturbed when, for example, the credibility of government is challenged. If truth, in final analysis, is subjective, then that fact should be faced and dealt with. The truth about the Supreme Court of the United States is difficult to ascertain. Enveloped in secrecy in its deliberations, issuing few public pronouncements other than written opinions which are often "desperately negotiated documents" or the products of a process of bargaining, the Supreme Court is further submerged in a fog of myth and ritual. It has not received sustained attention from scholars who will study it as an institution and as an instrument of government with "a legitimate political function to perform."109 As with the avowedly political organs of government, its power rests ultimately upon whether the decisions it makes, as Frankfurter wrote, "rest on fundamental presuppositions rooted in history to which widespread acceptance may fairly be attributed."110 Or as Professor Alexander Bickel has said, "The Court should declare as law only such principles as will-in time, but in a rather foreseeable future-gain general assent."111 If one replaces the "should" of that statement with a "can," then it would seem that Professor Bickel would tend to agree with the tenor of this paper. In any event, candor about government is desirable: why should a few intellectually sophisticated scholars bamboozle the people back home? That is "squid" jurisprudence-hiding the truth about the Court behind a

whole people. Otherwise the rule becomes a mere opinion-a thought he does not wish to entertain. ... In the United States the extent of judicial lawmaking is both greater and more frankly recognized than anywhere else. Nevertheless, this does not mean that our judges like the system. It is well known that Judge Learned Hand and Justice Frankfurter have expressed a deep aversion to the notion that even in constitutional questions the courts take any legislative initiative. Preferably they should rely on the legislature to have the last say whenever possible, and when that has failed they should place their trust in community sentiment." ShkLAR, LeGalisM 101.02 (1964). See Stone, Social Dimensions of Law and Justice 678 (1966): "Citizens left to believe that burdens flowing from a judgment inevitably flowed from pre-existing law, when in fact decision on the law might have been the other way, are in a sense being deceived. The right to know the architect of our obligations may be as much a part of hiberty, as the right to know our accuser and our judge."

${ }^{100}$ Alfange, The Relevance of Legislative Facts in Constitutional Law, $114 \mathrm{U}$.

PA. L. REv. 637, 639 (1966).

${ }^{110}$ Quoted in Bickes, op. cit. supra note 66, at 238-39.

111 Ibid. 
cloud of inpenetrable ink. ${ }^{112}$ While doubtless it is desirable to maintain secrecy about the internal deliberations of the Court, we too have an abiding conviction that truth is better than fiction. We feel, further, and will attempt to demonstrate in Part Two, that unless the Supreme Court adjusts itself to changing reality, it will plummet in power.

\section{Appendix}

The following is a questionnaire which was sent to selected students of the Supreme Court in an effort to elicit opinions about the role of the Court.

1. In your judgment, what is the basis for the high esteem in which the Supreme Court is held by the American people generally? Is there a difference with other courts-e.g., state courts or trial courts?

2. Would it harm the Court as an institution if people generally adhered to the beliefs of the "legal realists?" Why?

a. In this connection, do you know of any studies which have been made to develop empirical evidence on the question?

3. If the "legal realist" view of the judicial process is reasonably valid, should it be kept from the public even though known to the intellectually sophisticated? Why?

a. In this connection, is there a utilitarian function to the ideal of a "government of laws and not of men?" Thurman Arnold says that "briefs could not be written before a court on any other premise. This very simple ideal is essential to the public acceptance of our judicial system and to all steps in the judicial process." 113 What do you think?

112 The late Morris Raphael Cohen gave effective refutation to the squid jurisprudents when he stated: "When I first published the foregoing views [on judicial legislation] in 1914, the deans of some of our law schools wrote me that while the contention that judges do have a share in making the law is unanswerable, it it still advisable to keep the fiction of the phonograph theory to prevent the law from becoming more fluid than it already is. But I have an abiding conviction that to recognize the truth and adjust oneself to it is in the end the easiest and most advisable course. The phonograph theory has bred the mistaken view that the law is a closed, independent system having nothing to do with economic, political, social, or philosophical science. If, however, we recognize that courts are constantly remaking the law, then it becomes of the utmost social importance that the law should be made in accordance with the best available information, which it is the object of science to supply." CoHEN, LAW AND THE SOCIAL ORDER 380-81 n.86 (1933).

${ }_{118}$ The quotation from Thurman Arnold is taken from a letter of March 23, 1966, from him to the senior author of this article and is used with permission. Similar views may be found in ARnold, FaIR Fichts and Foul (1965). See Miller, Book Review, 15 AM. U.L. REV. 160 (1966). 
The following are eight of the replies received from recipients of the questionnaire. They are reprinted as received. It must be emphasized that while permission to print these replies has been granted by each of the writers, none of them has read the text of this article; in no way should they be considered as approving (or disapproving, for that matter) anything contained therein.

I

\section{Question 1}

Respecting "the basis for the high esteem in which the Supreme Court is held . ..," I am going to read "basis" as "factors accounting for," and I am going to assume that your reference to "American people, generally" means that you realize that the Court is not held in "high esteem" by some groups, e.g., strong supporters of segregation, but that you do not want me to address that aspect of your question. I will not therefore directly touch that question. But, I think what $I$ have to say will necessarily have implications for who holds how much esteem for the Supreme Court (or some person or persons within it) through selected periods of time.

Turning, then, to the "factors accounting for" the Court's high esteem, I must generalize without systematic empirical foundations, thus to some extent merely speculate about the causative agents. Some people may hold the Court in high esteem because they study its work very carefully with great understanding and perceptivity, are thus well aware of the difficulties it faces when problems of choice are presented to it, and appreciate, indeed may admire, the attempts of the Court (and individual justices) to be as frank and candid about the premises of its decisions as it can. For example, this group might hold high esteem for the Court because of the frankness with which the policy components of the choice which the Court faced in Barr $v$. Matteo [360 U.S. 564 (1959)] were stated in the several opinions. Esteem and respect could derive here from understanding and appreciating the diffculty which the court faced in resolving a problem for which there is no pat answer, and from the conviction that the Court was honestly, conscientiously, in the finest judicial tradition searching for the solution which was most in accord with the values of the national community. (My guess is that this group is not large in number, being composed principally of professionals and academics. The vast majority of the American people probably do not study the Court closely enough to react to the kind of variables that infiuence close students of the Court.) Some people may hold the Court in high esteem merely because it is identified as part of the United States Government. Some may hold it in high esteem simply because they defer to and esteem established authority. (The reverse may also be true of some people, i.e., anti-authoritarians holding authorities in low esteem.) Some people may hold the Court in high esteem because they believe (basically because it is reputed to be so) the Court has an expertise and wisdom deserving of such esteem. Finally, some people may hold the Court in high esteem because they believe it has some means, of which few men are gifted, of "finding" the law. The most general hypothesis I would advance, however, is that the esteem of the Court (the degree to which the population holds supportive attitudes toward it) is a function of the extent to which the population regards the outcomes of the Court's decision-making as indulging or depriving their own values, both their purely personal values and their ideological values. This hypothesis may be in need of further refinement. Conceivably supportive attitudes are a function of the congruence between the Court's conceptions of problems, values at stake, models of cause and effect or probability relations, alternatives, and predictions, and the population's conceptions of these components of a policy choice. It is also quite likely that over time the court builds up or tears down a "bank" of supportive attitudes upon which 
it may draw in times of stress. Consult David Easton's discussion of the relation between system outcomes and supportive inputs to governmental systems in EAsron, A System ANalysis of Polmical Life (1965).

I have no doubt, I might add, that new insights would be realized from a sustained, careful effort to put the question, "what is the basis for the high esteem . . ." into a form that is operational for the purpose of an empirical research study of Amcrican attitudes toward the Court. I think such a study would conclude that most of the talk about estecm of the Court is exceedingly loose.

Respecting attitudes toward trial courts and state courts, my hypothesis is that they do not enjoy as much esteem as does the United States Supreme Court, even from the population in their own jurisdictions.

\section{Question 2}

As to the second question, I assume that what is meant by "harm" is decreased esteem for the Court. But I do not know what to assume is meant by "beliefs of legal realists." If this expression means that judges use their purely private and personal value system as criteria for deciding cases to the exclusion of community values (statutes, rules, etc. included), I think this belief by people generally would lead to a decrease in esteem for the Court. If "belicfs of legal realists" means that the legal realists hold that legal propositions do not decide concrete cases, but that judges make a policy analysis or react in an idiosyncratic way, my answer differs. I do not believe that the Court's esteem would suffer because people believed the Court made a policy analysis, at least among the people who do not belicve that the "law" is to be "found." The Court's esteem would suffer, $I$ believe, if people believed that the Court's decisions were merely the resultant of idiosyncratic reactions of individual justices. I would also hope that the Court's esteem would not suffer merely because in a given case its decision appears to be an example of a relatively mechanical application of pre-existing rules to facts. In some instances highly programmed (minimum discretion) decisional systems may work better than less highly programmed ones. Of course the reverse may be true. But to say which approach is better we must appraise the operation of both types of decisional systems in. terms of criteria of "working well." It is of course a most diffcult question whether to decide a particular case relatively mechanically, or, perhaps at the price of overruling past cases, to decide it after a full-fledged policy analysis. But, to sum up, with these qualifications $I$ do not believe esteem for the Court would suffer if people generally adhered to the beliefs of the "legal realists." Indecd, more realism among the population might Jead to increased esteem for the Court.

I will go one step further: justifying decisions by question-begging use of legal citations, or legal mumbo-jumbo, or vague appeals to metaphysical concepts may lead to Joss of esteem for the Court. I believe that the population steadily is becoming more intelligent and rationalistic and is increasingly demanding rational decisions from legal process. Perhaps it is mostly my personal value system that is speaking, but I also believe that people in general share my belief in the principle of accountability respecting public officials. This principle calls for visible decisions-visible in the sense of who made them, when, and for what reasons. To fail to give the felt reasons, or to obscure them, offends the accountability principle. Moreover, hidden decisions are very often a reflection of an arrogant attitude toward people generally. It is, I hope, apparent why $I$ believe that a realistic view of legal process should not be kept from the public. In fact I think it is decidedly healthy to tell the people the truth, and I think the Court is the best agency to do the telling. Possibly, the bar and legal educators are remiss in failing to launch a general educational program designed to acquaint the population at large with the difficulties of choice that the Court faces, and to develop an appreciation for its role. Such a program might do wonders for improved esteem. 
Question 3

As to the government of laws and not of men idea, and whether it serves a utilitarian function, the first proposition is too loosely stated. It invites one to formulate a dichotomy-no discretion in the Court at one extreme, and unlimited discretion in the Court as the other. The truth lies somewhere in hetween, but not always at the same place in between. We are dealing with a continuum, not with a simple dichotomy. Now I think there is often utility to a decisional system so highly programmed that discretion in individual applications is held to a minimum (discretion in such a system is largely that of the designer of the system) because it may produce quicker, less expensive decisions. Moreover, it may appear very impartial. But such a system may in fact be dysfunctional in some instances. The quick inexpensive decision may prove to be neither quick nor inexpensive if it is so poor that its effects breed the necessity of many other decisions. Moreover, detachment and impersonality can lead to dehumanization. Of course, similar pro and con comments can be made of the use of highly discretionary decisional systems in some contexts. So $I$ answer the first question in $3 a$ as yes and no, it depends.

I think Thurman Arnold clearly overstates his point. Certainly when one drafts a brief one acts on expectations that certain legal propositions will be invoked by the Court. (Lawyers are not always successful, however, in predicting the doctrinal propositions which a court may fecl are relevant;-see Mermin's recent study of a very important Wisconsin case [MERMIN, JURISPRUDENCE AND Statecraft (1963)].) But surely Arnold does not act on the expectation that the only acceptable decision "under the law" which the Court may render is the one Arnold urges. Surely he doesn't assume that the opposing attorney is stupid, or uninformed, or mistaken, or asking the Court to act illegally. I don't think Arnold is saying any of these things, although his choice of words might permit such inferences. Rather, I think he means, or should mean, that without well-founded expectations that certain value standards are accepted by the Court as limits on their discretion, argnment would be meaningless. I agree. But $I$ would add that meaningful arguments might still be made although the Court felt that it faced a brand new issue, and that all legal analogies were of no help. To argue in terms of what public policy should be is not to abandon the idea of a government of law. To the contrary, the practice of advancing arguments respecting what policy should be defers to the idea of a government of law. Any such argument asks a properly constituted institution of legal process to prescribe a legal proposition to govern a case for which no rule particularly tailored to the case exists. This situation is perhaps most apparent, and perhaps the most extensive in scope, example of creative law-making. But law-making also takes place in deference to legal principles. Legislatures must legislate in accordance with constitutional principles. If the case of the Court construing constitutional provisions against completely new fact situations is cited, $I$ concede that no legal proposition may be infiuential on the merits (although of course many legal propositions will have been infiuential in developing the record and defining the issue). Even when this is true, and the Court feels that it is making new law without the aid of legal propositions, it does not have to retreat to an idiosyncratic approach. We expect our law makers (judges included) to make law, but to make law that they conscientiously believe is good for the community. We expect them, then, to make a complete policy analysis. In making that analysis there are some general principles which may serve as guides to decision, although they do not dictate decision. One such principle is to carefully formulate the problem for decision (get the facts, its dimensions, etc.-this means formulate not merely the legal problem but also its societal counterpart). Another principle says identify the social values at stake. Another says formulate realistic alternatives. Another says estimate the efficiency of these alternatives. And a final one says choose the alternative which maximizes the public interest. I don't mean to minimize the difficulties that may attend such an openended approach. But $I$ do mean to assert that in our tradition this approach is not 
lawless, nor without constraints upon personal idiosyncracy, but upon the contrary honors the ideal of the Rule (not rules) of Law.

Thurman Arnold, I'm afraid, has seriously over-simplified the problem.

\author{
Ernest M. Jones \\ Professor of Law \\ University of Florida
}

\title{
II
}

\section{Question 1}

Those who hold the Supreme Court of the United States in uniquely high esteem, distinguishing it in this respect from the state courts and the inferior federal courts, do so because the Supreme Court of the United States exercises the power of judicial review over decisions of state courts and enactments of federal and state legislatures. Public hostility to the Court stems primarily from the same source. As the Court exercises the power more militantly, more and more of those in the middle of the road will tend to join this group of adverse critics of the Court. To the extent that the Court hesitates to exercise its power, it avoids this danger, but disappoints the expectations of its strongest supporters. From the point of view of its own prestige, as well as the point of view of its proper function, the most important thing that the Court does is to exercise its unique power responsibly. (I give a nod of respect but disagreement to the view that the most important thing the Court does is "not doing.")

\section{Question 2}

Responsible exercise of the power of judicial review must be responsive to the needs of the society in which we live if the Court is to maintain its prestige. Public allergy to the law itself as an institution stems primarily from its engagement with considerations that appear to be irrelevant to these needs. The same may be said of the Supreme Court. The irrelevant considerations which can damage the Court's prestige are, of course, quite varied. In earlier decades, the Court was probably judged more by the results reached in a particular case than by the public rationalization in the Court's opinions, but advances in public education and in communications have altered this balance and are continuing to alter it. No amount of public loyalty would permit the fabled emperor's lack of clothing to go unnoticed if a television camera were trained on him. For the same reasons, unsatisfactory rationalization of its results becomes increasingly damaging to the Supreme Court of the United States as an institution. Thus, an opinion that seeks support in non-existent legislative intent, whether of the framers of the Constitution or one of its amendments, or of the Congress that enacted the Wagner Act or the Taft-Hartley Act, not only is unlikely to produce a sound decision; even if it does, it carries potentiality of damaging the Court's good repute.

Upon rereading question 2, I realize that $\mathrm{my}$ answer does not meet it directly. What I am saying is that more and more people are coming to adhere to the beliefs of the "legal realists." In answer to question $2 a$, I do not know of any empirical study on this subject. In further answer to the basic question, I feel sure that the present Court would fare better among "legal realist" critics than among critics clinging to disproved abstract conceptions of the role of legal institutions. But if the public is only partly transformed, neither is the Court's adherence to "legal realism" perfect nor complete. This entire answer, of course, makes certain implicit assumptions about what "legal realism" is.

\section{Question 3}

I do not believe that what courts actually do can Iong be kept from the public. And to the extent that the "legal realist" view of the judicial process is valid, I do not believe that it can permanently be kept from the public, when known to the intellectu. ally sophisticated. Assuming that the truth could be confined to the latter group, I 
do not believe that it should. Thus, for two reasons, I answer question 3 in the negative. Since the true nature of the judicial process cannot be kept from the Court's "intellectually sophisticated" adverse critics, auy attempt by the court itself or by its supporters to conceal the truth will naturally be characterized as intellectual dishonesty and deceitfulness by those hostile to the Court. Whether or not the general public can be made to understand the complexities of the judicial process as it exists in fact, the public can certainly understand accusations of this kind. Thus, in the long run, I believe that honesty is the best policy for the judiciary. Even assuming that the Court could conceal the true nature of its functions, I believe that it would be un. fortunate for the Court to do so. The Court is, after all, responsible to the public if only indirectly, through the limited powers that the executive and legislative exercise over the judicial branch. While a dictatorship by the judiciary is a most unlikely event, elimination of the pressures of public criticism by shrouding the work of the Court is undesirable for other reasons. First, it would certainly facilitate judicial surrender to improper assertions of power by the executive or the legislative branch. Second, it would impair social interests in certainty and predictability of the law made by Supreme Court decisions. If the published opinions of the Court are to be regarded only as buffers against the onslaught of public opinion, then the well-advised client should disregard those opinions. And the line that divides the "intellectually sophisticated" from everyone else can never be really a line anyway. We certainly cannot assume that all members of the Bar will fall on the proper side of it, and we can expect a similar division in the ranks of politicians, civil servants, and the public itself. The prospect of a not-so-intellectual practicing attorney attempting to advise a similarly unblessed goverumental official on the basis of Supreme Court opinions that were written to conceal rather than reveal the springs of judicial action poses an obvious threat of total chaos.

Thurman Arnold is at least half right. I would say rather that briefs can be and are written on the premise that ours is a government of laws as well as men. The Constitution, legislation and judicial precedent all play important roles, but we would be foolish to believe that electronic data retrieval can ever replace the creative role of adjudication. This is obviously even more true of the Supreme Court of the United States, because of its powers of judicial review, than it is of any other court. Realism does not require rejection of the role played by laws; it requires, rather, recognition that laws without the intervention of courts are only part of the story. Any lawyer who wrote a brief before the Supreme Court of the United States exclusively on the basis of cold precedent, without regard for the creative function of the Court, would in most cases have left the job only partly done.

Thomas S. Currier

Professor of Law

University of Virginia

\section{III}

\section{Question 1}

I suspect that the basis for high popular esteem of the United States Supreme Court is in large measure popular acceptance of (a) the declaratory theory of law, removing from popular imagination any discomforting doubts which would naturally attend an explicitly recognized value-making and means-to-ends-choice-making role, plus (b) the popular image of the blind goddess with the scales, or the stalwart male figure with the sword, signifying-to the inan in the street, at least-the idea of impartial adjudication, demanding simply fair application of already known, existing doctrine. I have no Gallup poll to back me up, and don't know whether any of the pollsters' past questions supply empirical data or not. I would cite the general fact-I think it to be a fact-that most of the really hot public controversies about the judicial role have arisen not out of disputes over the correctness of integrity of the adjudicative role 
(notable exceptions, of course: e.g., Sacco and Vanzetti), but over the lawmaking role when that has come sharply to public attention (child-labor decisions, Dred Scott, invalidation of New Deal Legislation).

\section{Question 2}

I think you must ask, which legal realists? It would barm the Court and the country if popular opinion adopted the sophomoric cynicism or inside-dopester weaknesses of some fringe realists (e.g., Pearson and Allen). Healthy government with some substantial popular base should be advanced and not harmed by a maturely realistic appreciation of low institutions should operate in order to fulfill the abiding values of the society; in such a context, if realism hurt the Court, it would be only because the Court was not behaving well. Of course, liealthy, popular-based government requires unifying symbols, and symbols add an emotional dimension to views of institututions: that is largely their function. But society has to run with a good deal of emotion as well as reason; the question must be, whether it is emotion responsibly disciplined by reason. I am sorry that I don't know of empirical studies to back me up. There are some disquicting empirical studies on the other side of the coin: of the dubious attachments of common opinion (notably of young people's opinion) to values like Bill-of-Rights values, which need sound emotional underpinnings for survival.

\section{Question 3}

Again, your question can't be answered without very careful definition of just who are the realists whose sophistication is in issue. And, again, a healthy legal order which seeks a substantial popular base, can't run simply on empty symbols or unreal concepts; thouglı it will probably always be a race with catastrophe, I sec no other workable tack to take except the Jeffersonian one of educating at least a broad spectrum of the people to the extent that they know something of low to define where their real interests lie and how to look after them. I think the Court would be stronger for there being a broadly pervasive, responsibility realistic understanding of (a) the considerable measure of policy-making discretion which has always resided in it and must continue to reside in it, coupled with (b) the consequent need for defining standards (e.g., a meaningful presumption of constitutionality) to which to hold the Court in exercising its discretion and in not improperly trenching upon the legislative and executive branches.

(a) There is utilitarian function to the idea of a "government of laws and not of men," if the phrase is taught as spelling the demand upon public officers to exercise judgment by criteria derived from broad community ideals, tested by application of reason to facts and to acute definition of involved interests and values, and not derived from the peculiar or parochial experience or prejudice of the particular officials. If the phrase is taken to mean an appeal to the "brooding omnipresence," then dependence on it seems to me sophomoric, if only because in the long run it won't work.

Willard Hurst

Professor of Law

University of Wisconsin

\section{IV}

\section{Introduction}

I am delighted to hear that you plan to have a go at Mishkin, with whom I also disagree (at least in part). I first came into the prospective overruling angle when I was at the University of Virginia Law School in the fall semester ' 64 , and had a chance to exchange ideas with Tom Currier of the Law School on some jurisprudential aspects of his pre-Linkletter article [Time and Change in Judge-Made Law: Prospective Overruling, 51 VA. L. REv. 201 (1965)]. I think Tom and I are agreed that in the choice 
between certainty/consistency/predictability/stability and flexibility/creativity/socialadaptation/justice, there are certain basic values or interests inherent in our whole case law system, which normally operate to support the former set of demands (though Tom's list of these values at 235-37 is not quite the same as mine). The prospective overruling problem arises because in some situations some of these values may turn out to work against their normal implication of adherence to precedent. When this happens, these errant values must still be weighed against the others by an ad hoc consideration of the instant case. Consequently there is practically nothing that can be said at the general level as to how the weighing of values should turn out. But perhaps it can be said that if the instant problem itself has any special features which have the cffect of "loading" one of the values being weighed (as in my view the linkletter situation ought to "load" the value of equality), then that should be enough to tip the balance.

The Linkletter opinion is itself so close to this approach that all that $I$ can really say by way of criticism is that when it came to the ultimate ad hoc weighing of values which such an approach demands, the Court's weighing of the values involved came out differently from mine. But there is one thing which perhaps affected the result. The above analysis would imply that prospective overruling is always a sometime thing, with retroactivity continuing to be the norm: and this corresponds with what I understand to have been the use of the device up to now. In the Linkletter litigation this position seems to have been somchow switched around, so that there was (as it were) a presumption that Mapp v. Ohio [367 U.S. 643 (1961)] would operate only prospectively, and the appellant was put in the position of having to show reasons why this presumption should not apply.

I am, of course, at a disadvantage in discussing prospective overruling. In Australia we have no such animal. My own experience is limited to my brief flirtation with the Curricr article, and some equally brief preliminary work with my own teacher, Julius Stone, on the prospective overruling section of his Social Dimensions of LAw AND JUstice 658-67 (1966). Similarly, with regard to your questionnaire, I am in. clined to think that anything I can say will have little value, because of my limited and largely impressionistic awareness of relevant American conditions. Such insight as I may be able to bring to the problem would stem, $I$ think, from two sources. One is my own crude but continuing attempt to articulate the contrasts between Australian and American judicial systems, both as to technique and social impact. The other is my own long perplexity over your questions 2 and 3 , not so much as raised by legal realism itself, but rather as raised by my own involvement with Stone's position now most fully set out in Chapters 6.8 (especially Chapter 7) of his LEGAL SYsTEM aND LAWYERS' REASONING (1964).

For me, those chapters raise two fundamental but still unsolved questions. First, Stone's position (which I entirely accept) does not require us (as "realism" did) to reject the orthodox concentration on rules and precedents altogether: it requires us to see that certainty/consistency etc., and flexibility/creativity etc., are both im. portant aspirations of the legal system, and that by working with the orthodox precedent apparatus, judges do in fact manage to achieve realization of both of them. But exactly how is the balance to be struck in stating this position? In particular, how is the certainty/consistency set of demands (to which $\mathbf{I}$ would add rationality and "soundness" of argument) to be stated without plunging us back into the overcmphasised orthodoxy that the "realists" pried us free from? (Obviously the importance of Wechsler's "neutral principles" [WeCHsLER, Toward Neutral Principles of Constitutional Law, in Principles, Politics and Fundamental Law 3 (1961)] is that they represent an attempt, though a verbally muddled one, to solve precisely this problem.) Second, if "realism" (or Stone's extension and modification of it) is right, should we say so? This last is, of course, exactly your question 3; and as far as I can see we still haven't managed to produce any better diseussion of it than the crude Demogue-and-Wurtzel chapters in FrANK, LAW ANd THE MODERN MIND (1930). Stone, I think, would regard the whole of pages 652.96 of his 1966 book referred to above (and especially perhaps pages 677-78) as an attempt to help us with these very ques- 
tions; but for my part I am still just as perplexed as ever. At any rate for what they are worth, my answers would be as follows.

\section{Question 1}

In Australia, law and government tend generally to be seen as rather remote from relevance to ordinary daily life. Legal and governmental functions are seen as important, but they tend to be left to their specialist functionaries: "ordinary" men are concerned with ordinary things. This means, of course, that along with apathetic unconcern for the doings of lawyers and politicians there goes a good deal of respect, of the kind accorded to any specialist in an esoteric but important field. Yet for both lawyers and politicians, this respect is coupled with a certain degree of scepticism and even contempt, such men being seen as "manipulators."

There are, however, projected onto this mixture of favourable and unfavourable popular attitudes, certain hierarchical value-ascriptions originating within legal circles themselves. Judges tend traditionally to be scen as more dignified, wiser and more just, possessed of higher intellect and higher integrity, than ordinary lawyers; and ability and dignity are also assumed to increase in an ascending scale as we move progressively from magistrates' courts to the highest judicial tribunal. Consequently as to most judges, and a fortiori as we near the top of the judicial hierarchy, judges tend to be freed from the "manipulative" stigma which attaches to lawyers generally, and popular respect for them is correspondingly more unreserved. Finally, the respected status which judges thus occupy allows them to speak out extrajudicially from time to time, as spokesmen of "official" public opinion on controversial issues; and these extrajudicial pronouncements further enhance their public image as "ideology makers." This last function, in Australia at least, tends not to be exercised by judges of the (federal) High Court, but by a few particular judges of the State Supreme Courts; but perhaps the enhancement of the public image of the judicial office extends to all holders of that office.

All this, I should gness, is more or less true for all common law countries; and represents a kind of minimum model for the answer to your question. For the United States, however, this model needs to be supplemented (and in part modified) by reference to further important factors.

A first factor, particularly striking for an outsider, is the high degree of "law awareness" in the American community. Not just legal philosophers, but people generally, regard the idea of law as fundamental to American society; and this must appreciably enhance the popular respect for lawyers which is present even in my "minimum" model. Second, this "law awareness" is particularly striking in relation to the Constitution. In Australia the constitution is no more revered (and hardly any better known) than if it were an ordinary Act of Parliament (as in fact it is); in the United States it is popularly reverenced to a degree that amazes the outsider. As a foreign jurisprude, I Jike to believe that U.S. law-awareness in general, and Constitution-awareness in particular, have a deep historical linkage with the origins of the whole polity in a people's rebellious choice of its own destiny, based on a natural law ideology-which, of course, I disapprove of as a positivist almost as much as I do as a Britisher! Whatever the explanation, the popular reverence for the Constitution is real, and must rub off on the institution whose work is primarily associated with the Constitution. The President's symbolic identification with the "idea" of the Constitution is a major source of his high esteem; the Supreme Court has its own kind of identification with the same symbolic "idea," and it reaps the same rewards in public assumptions. Third, this factor acquires special importance from the fact that the workload of the Court is in fact almost wholly confined to its constitutional functions: where, as in Australia, the "Constitutional" court is also the highest national court of appeal in "ordinary" litigation, it tends (even in its constitutional work) not only to function in fact much more like an "ordinary" court, but to be regarded as such. Fourth, within the framework of its "constitutional" functions, the Supreme Court does in fact have occasion to pass judgment on almost every aspect of American litigation, consequently touching almost every aspect of American social life. Supreme Court Justices then tend to be projected 
as ultimate arbiters of every aspect of "the American way of life." What makes this fourth point not inconsistent with my third is that, fifth, almost all the Supreme Court's work is widely and intelligently reported in the press. If fully reported the diversity of our High Court's "ordinary" appellate work might give it, too, the image of an ultimate arbiter of life in gencral. In fact, however, press coverage is given only to those of its judgments which are-thought to touch on either "vested" or general popular interest, mainly in the constitutional and criminal law ficlds; and even then the reportage is usually garbled to the point of unintelligibility. By contrast the United States Supreme Court owes much to its press coverage. Sixth, in Australia almost all law graduates go into "ordinary" professional practice. Consequently all our judges, including High Court judges, are still drawn from the ranks of men who have successfully practised at the bar. (On three or four occasions, as with the present Chief Justice, a man has been appointed straight from the political office of Common. wealth Attorney-General, but even this is always at least pJausibly referable to the appointee's former outstanding career as a practising lawyer.) This means that we can still maintain, with a substantial degree of truth, the myth that judges (and particularly High Court judges) represent the best and most talented of our legal profession. In the U.S., the distribution of good law graduates through a wide range of governmental, academic and other occupations in addition to "ordinary" law has founded a similarly wide range of sources from which judicial appointees are drawn; and occasionally, of course, the selection reaches outside the range of law graduates altogether. The myth equating judges with "the best lawyers" then becomes less maintainable; and Supreme Court Justices may to that extent get less respect than their Australian brethren. But this, I think, is offset by the fact that the American practice also means that it is almost a matter of course for appointees to be men already marked out as outstanding personalities in the public eye.

I gather from my discussions with Stone that he would want to elaborate very considerably on the fourth factor I mentioned above. I would not exactly disagree with his elaboration, but I would tend to regard it as of inspirational rather than reportive value. Roughly, the elaboration would run Jike this. Mishkin's approach to the Court's symbolic function harks back finally to the old maxim that it is more important that a matter be settled than that it be settled right. But what we should rather say is that it is morc important that a matter should be settled as right as possible for the time being than that it be not settled at all. At page 795 of SocinL DIMENSIONS OF LAW AND JUSTICE, Stone comes close to this view in discussing the "demand of justice" that the legal system should provide institutionalized outlets for the unavoidable tensions of a pluralistic society: "The Supreme Court of the United States, in those very aspects at which British Jawyers sometimes look askance, offers a supreme example of this provision. The very varied outlooks and talents and capacities of its members often spell discord. Yet its very discord may symbolize the will of so richly complex a people to Jive under broadly agreed principles, and also to sublimate the bitter disagreements which broad principles so often yicld in applica. tion." In now wanting to expand this suggestion, I gather he would say that most members of the American community now realize that the fundamental policy issucs that the Supreme Court has to deal with are not capable of legalistic answers, nor of any absolutely right answers capable of Jasting for all time. In face of these problems, he would say, the Supreme Court represents an expedient which appellate courts in other countries may yet have to follow: a resort in effect to the "wise men" syndrome in the hope that the settled policies for the time being, while necessarily imperfect, will be the best available.

\section{Question 2}

In answering your second question, I shall take "legal realism" to refer to all the views-from "extreme" realism to (at least) its more moderate latter-day versionswhich in fact recognize a substantial measure of judicial creativity, and a substantial degree of illusoriness in the legalist's rule-and-precedent structure. I simply do not 
believe that popular acceptance of any of the views thus included would do any substantial harm to the efficiency or prestige of the Court as an institution. In the "minimum model" which I constructed from Australian conditions, such a view if popularly held would no doubt increase the weight of the "manipulative" slur as an ingredient in popular attitudes; but I believe the overall balance of factors in this minimum model would still be in favour of respect. Of the specific American factors which I added to this minimum model, the first and second do not (in my naturallaw-tending explanation of them) entail a belief in "law" or "Constitution" as a specific set of black-letter rules; the focus of respect is rather on the "idea" or "spirit" of law as a means of rational guidance of a country's destiny, and a substantial measure of judicial creativity is perfectly consistent with this. My third and fourth factors, insofar as they focus on the functions that the highest tribunal is believed to perform, are I think in no way affected by any beliefs about the techniques employed in performing those functions. (As to the "ultimate arbiters" angle of my fourth point, see below.) My fifth point, as to press coverage, perhaps suggests a basic fiaw in your whole second question, or at any rate a reason for difficulty in trying to answer it: namely that the full press coverage of the United States Supreme Court does already, I think, import a good deal of "realism," with no notable ill effects.

My sixth point perhaps suggests different answers for Australia and the U.S. What it does is crudely to contrast two alternative bases of respect for high appellate judges: the Australian "best lawyers" basis, and the American "outstanding personalities" one. These nationally-oriented equations are of course extremely rough, and each alternative factor is confined to a minor subsidiary role in popular attitudes. But for what it is worth, I suppose that "realism" popularly imbibed would somewhat detract from the "best lawyers" basis for respect (insofar as it might make legal qualifications less important to good adjudication), and would correspondingly enhance the importance of the "outstanding personalities" basis. To this extent "realism" might actually strengthen popular respect for the U.S. Court.

This leads me to consider Stone's "wise men" version of my "ultimate arbiters" point. The belief that he would seem to ascribe to most American citizens is: Ultimate policy problems are not finally or permanently soluble; all we can do is to work out guidelines for them from time to time; in the U.S. we do this by leaving the job to a bench of nine wise men representative of different ideologies. And, he seems to say, most Americans would add to this belief the evaluation: This is the best solution any nation could devise.

Now, I suppose I must agree that many American citizens would hold the above belief; but I think the above evaluation would be added only by those who think that by and large the Court's results are right. Many other Americans would also hold the above belief, but would add the different evaluation: Surely there must be something better we could do. I also think that, in addition to these two classes of citizen-approving believers in the "wise men" syndrome and disapproving believers, there would be many other citizens who would not share the above belief. But these, too, would be divided into approvers and non-approvers of what the Court does.

No doubt popularization of "realism" would tend to shift the balance between believers and non-behevers in the above belief; there would clearly be more "believers." But within the changed belief framework, it seems to me that the balance between approvers and non-approvers would not be substantially altered. Possibly Stone would even say that more of popular "realism" would spread both belief and favourable evaluation; if so, I would disagree. But while I do not thimk more "realism" would diminish popular criticism of the Court, I don't think it would increase it either. In other words, whether or not judges are or should be "result-oriented," I think that popular evaluations of judges clearly are so oriented.

So much for the effects of widespread "realism" on popular attitudes. Thus far, in effect, I see no real problem. But if we interpret the words "people generally," as used in your question, to include the Supreme Court Justices themselves, I become very much more worried. In relation to our High Court, my estimate is that most 
of our judges do in fact exercise a substantial degree of creativeness, but that they do not in fact (with one probable exception on the present bench) "generally adhere to the beliefs of the 'legal realists' "-nor to any view placing substantial stress on judicial creativity. If this were to change, I do not believe that there would be any striking change in the patterns of judicial behaviour of our present generation of judges; but I honestly do fear that the next generation might be the worse for it. I do not know. But my fears are prompted by the very things that trouble me, and also many other observers, with regard to your Supreme Court, where I think it is fair to say that there is a fairly widespread judicial belief in something like "realism."

My worries are twofold, and the first of them relates precisely to the effect on "the Court as an institution." It is, I think, the same kind of worry as Bodenheimer expresses at the tail end of his piece [Birth Control Legislation and the United States Supreme Court, 14 Kan. L. REv. 453 (1966)] on Griswold v. Connecticut [381 U.S. 479 (1965)], where he talks about "the spectacle of nine philosopher Kings at war with eacl other," and pleads for "a strengthening of the institutional approach by the Court, as distinguished from an exclusively individualistic attitude toward ... constitutional interpretation." It seems to me that this excess of personal sound and fury is the main complaint to be made about the Supreme Court in recent years. In part, I suppose, the same comprehensive press coverage as I was praising earlier is responsible for throwing individual Justices under a personal limelight to which they feel that they must play up; and perhaps all we academics in our Law . Review commentaries also encourage this. But I think also that judicial imbibing of "realism" must share a part of the blame for the tendency to write as nine individuals rather than as an institution. The present pattern translates the "star" system from the movies to the Court. It may be, as I suggested earlier, that this does no harm to the prestige of the institution, and may even enhance it; but $I$ think it does no liarm to the prestige of the institution itself.

My second worry is epitomised in my anxieties [Constitutionalism and Comstockery, 14 KAN. L. Rev. 403 (1966)] over the Douglas opinion in Griswold v. Connecticut. Whether or not I am right in thinking that Stone wants to modify "realism" by fincling some place, in his account of the judicial process, for certainty/consistency etc., $I$ cer. tainly want to do this. Lawyer-like patterns of argumentation, careful rational work within a framework built up by precedent-in short, all that Mishkin wants to preserve in appearance for symbolic reasons, I want to preserve as reality for substantial evaluative reasons. I don't want to say that judges should be creative but should scem orthodoxly judicial; I want to say that they should be creative but should also be orthodoxly judicial. Our High Court, under the last Chief Justice, Sir Owen Dixon, went through a period when by and large it managed not only to $b e$ creative while stressing an appearance of legalistic values, but actually to get its creativeness out of its legalism. I still can't quite say how this conjuring trick is done, but whatever the secret, that is what I want all judges to do. Harlan, I think, is capable of it; but generally the present Supreme Court seems so concerned with "what it is doing in fact" that it ceases to be sufficiently concerned with the craftsmanship of opinionwriting. Perhaps for the immediacy of the moment "result-orientation" is enough; but for long-run contributions to a legal tradition, it just won't do.

\section{Question 3}

Again, I see no adequate reason why "realism," or whatever modification of it is reasonably valid, should be kept from the public; I really don't believe it will make much difference one way or the other. Most of this is covered in my answer to question 2. But again, if "the public" be taken to include the Justices themselves, I have serious doubts, and just don't know the answer.

I suppose the main arguments for full disclosure are (a) truth is truth and must always be told, and (b) Pound's old axiom that "Much will be gained when courts have perceived what it is that they are doing, and are thus enabled to address them- 
selves consciously to doing it the best that they may." Three or four years ago I would have taken these two arguments as conclusive. The main arguments that $I$ now see pressing against these are (c) power corrupts (a judge who knows he is being creative may become sweepingly creative; a judge creating unconsciously within the leeways of an "authority" system will be confined from molar to molecular motion, etc.); and (d) on the "realist" view the whole burden of choice of decisions-with full awareness that these are to constitute the only justice available, both for the individual litigants and for whole masses of the community-bears down personally on the individual judge. The Blackstonian myth, which cushions and seems to ease the pressure of this responsibility, may be the only thing that makes it bearable. My anxiety here is for what Stone calls (Social Dimensions of LAw AND JUSTrce 683) "the overall psychic economy of the man who is a judge, who has to perform not merely in this case today, but in an endless series of cases, day after day, and year after year." Perhaps both (c) and (d) are rather fanciful, and it may be that I would finish up still following (a) and (b). But the points I raised in the final paragraphs of my answer to question 2 are also relevant here, and not at all fanciful. I really think that if "public" includes "judges," your question 3 is an agonising problem.

In spite of what I have said so far, I do not entirely reject Mishkin's plea for the "symbolic" value of the Blackstonian declaratory theory. But, as already hinted, my real reason for wanting judges to preserve adherence to precedents and sound patterns of argument from them is that I think these things are important in their own right. And here I find that I must after all drag in $\mathrm{my}$ own version of the Currier list of "values" affecting prospective overruling.

In my version, I would want to say that the judicial process (indeed "law" in general) is not merely a device for producing the most just and expedient solutions to social problems, but a rational device for doing this: "law" does import a commitment to rationality in problem-solutions. "Rationality" here has Max Weber's double sense of referring (a) to the basing of decisions on consistent, well-grounded, and "principled" intellectual operations, and (b) to the organization of legal institutions and their facilities and personnel so as to achieve a maximum of coordination and efficiency and a minimum of friction and expense (in the sense in which economists speak of the "rationality" of an industry). Now, (a) imports values of consistency in statement from one case to another; of equality of treatment from one suitor to another; and of what the current crop of ethical philosophers call "universalizability" in the value-judgments that we take as a basis for decisions; and (b) imports values of stability in social arrangements, certainty in judicial pronouncements, and efficiency in the handling of the Court's workload. All six values do demand that right results be reached not just anyhow, but by reasoned elaboration of precedent.

Now if I can take the symbolic value of the phrase "a government of laws and not of men" as a shorthand reference to all these things that I see involved in the idea of "law" as a rational endeavour-or even simply as referring to the need for "reasoned elaboration" of precedent as a means to judicial creativeness-then I would agree that the "government of laws" ideal does have a utilitarian function, as helping to ensure the implementation of my six "rational" values. Similarly if the "premise" that Arnold has in mind is to be taken in this broad sense, I would agree with him. If, as Arnold's presence in your question leads me to suspect, the reference is merely to Mishkin's notion that we should preserve an appearance of "government of laws" by going through the motions of "reasoned elaboration" etc., for symbolic reasons for reaffirming our ritual commitments to the "rational" law way of doing things, then $I$ would also agree that this might have a utilitarian function. Somewhere within my overall view of the reasons for our need of "reasoned elaboration," there would be a place for this symbolic ritual reason; but it would be a very subsidiary reason, and one that I would prefer not to mention at all. For I think that this reason does get us back to "Demogrie's belief in the importance of deluding the public," and what $I$ want to 
find is a way of saying that the good judge is both a precedent man and a creative one, without being thereby committed to saying that he is "deluding the public."

Anthony R. Blackshield

Lecturer in Jurisprudence

Faculty of Law

The University of Sydney

V

\section{Question 1}

The American people have appeared always to maintain a remarkable respect for law. Perhaps part of the reason for this is, as Tocqueville suggests, that in a democratic society law is looked upon as the creation of the people, and, therefore, those who claim to share in the process of self-government are inclined to approve of law that they have putatively helped to make. Perhaps it is also that the general level of affluence that has been characteristic of American society has established a respect for the status quo, and law inevitably stands for the preservation of the status quo. In any event, the Supreme Court, as the authoritative interpreter of federal law-which, in the popular conception, may often be equated with American law-serves as a convenient focal point for this public esteem and reaps the benefit of it. Moreover, and probably more important, the Supreme Court, as the branch of the national government most clearly responsible for the support and defense of the Constitution, shares in the amazing reverence that the American people have always had toward that document.

There is an aura of infallibility attached to final judgments, and simply because the Supreme Court is final, as Justice Jackson noted, it is considered authoritative. Thus, it appears to be held in higher esteem than any other court in the nation. Similarly, state appellate courts, capable of reversing trial court judgments and more isolated in their activities, are more respected than lower state courts. I think it is true that federal courts, in general, are more highly thought of than state courts, and I believe that the greater respect is due to the fact that they represent the whole nation rather than merely a part. I doubt that this would hold true, however, in any of the states of the South.

\section{Question 2}

The views of the legal realists, as even Professor Mishkin's article makes clear, have undoubtedly won general acceptance in law schools and among lawyers. The qualifications and reservations that are frequently expressed in the law reviews are not in any real sense a rejection of realism, but merely a shift in emphasis to place stress on the existence of certainty and stability, factors which most realists did not deny, but which, in contrast to the Blackstonian theory, they refused to consider as necessarily controlling. While this acceptance of legal realism has caused members of the bar to look upon the actions of courts in a different light, it has not appeared to cause a significant lessening of respect for the judicial process. Holmes, by all odds the most influential of the realists, could hardly be said to have held law or the courts in disrespect-he simply insisted that judges not be allowed to use legal certainty as an excuse for blocking the attainment of social goals generally thought to be essential.

The point is that if the triumpls of legal realism has not denigrated the Supreme Court as an institution in the eyes of its most attentive and critical constituency, why should it be expected to have this effect in the eyes of the general public? The "declaratory theory" of the judicial process is a functional myth to the extent that is generally believed that the only alternative to a legal system in which judges merely find law is a system of judicial arbitrariness and irresponsibility. But I am far from certain that the general public views either the legal system or the work of the Court in terms of these simplistic alternatives. I would surmise, instead, that there is a 
vague but substantial awareness that the Supreme Court does not merely inexorably apply existing law regardless of the social consequences, but that it acts, and must act, with considerations of the public good firmly in mind-that is, that it acts, and must act, politically. In this regard, the most potentially dangerous myth is the one you describe in your article [Miller, Some Pervasive Myths About the United States Supreme Court, 10 ST. Lours U.L.J. 153, 162 (1965)] as "the myth that the Supreme Court is to be equated with a court of law." Citizens desire litigation to be decided, for the most part, according to settled and accepted rules, and do not want courts to depart from these rules for insufficient reasons-that is, for reasons unconnected with the general public good. While it is, of course, true that cases even in such mundane areas as contract and tort can involve vital questions of public policy, the cases of this type that occupy most of the time of the "courts of law" are usually of far less general significance, and may be disposed of in accordance wtih Brandeis' observation that, in most areas, "it is more important that the law be settled than that it be settled right." The Supreme Court, on the other hand, has the authority, which it is expected to exercise, to limit its jurisdiction to cases other than the ordinary. By definition, therefore the cases that come to it for decision, especially cases of constitutional law, do not have importance solely for the parties, but, as in reapportionment or civil rights, may have ramifications that are crucial to the entire nation. Thus, while "courts of law" should not be expected to decide a high percentage of cases involving Negro and white litigants in favor of the Negro, the Supreme Court, hearing, with few exceptions, only those Negro.white cases involving crucial constitutional questions of justice and deprivation of civil rights, may justifiably be expected to decide much more frequently in favor of the Negro, so long as settled rules operate to perpetuate a system of racial injustice.

I know of no studies that provide any direct empirical evidence on this question. Without exception, every statement that I make here is based on nothing more substantial than intuition.

\section{Question 3}

Whether legal realists should keep the truth to themselves or should allow it to reach the public depends on the extent to which the public is disabused of the notion that it is unwarranted for the Supreme Court to decide cases even partially on the basis of extralegal considerations. There need be, therefore, no conscious suppression of the views associated with "legal realism," provided only that care be taken that revelations of the political aspects of the work of courts, and particularly the Supreme Court, be accompanied with at least implicit assurances that the law-making function of the judges is entirely proper and, in fact, utterly indispensable, that considerations in constitutional cases are different from those in ordinary litigation, demanding a correspondingly different judicial response, and that nothing in this judicial activity necessarily detracts from the dignity of the law. In this light, there is perhaps more danger to be apprehended from the stubborn denial that courts perform a political function than from the chance that the word will get out to the uninitiated. As Martin Shapiro put it in a brief but cogent argument against the preservation of the "declaratory theory" [Stability and Change in Judicial Decision-Making: Incrementalism or State Decisis?, 2 LAW IN TRANSmTON Q. 134-136 (1965)]: "[I]f scholars continue to state that courts are not political, the consequences are going to be worse for the courts than freely admitting that they are .... The present situation is one in which the public knows the courts are political, but thinks that they should not be, need not be, and are currently in a state of aberration from their normal condition of apoliticism." One of the weaknesses in Mishkin's argument, which was much more exaggerated in the preceding Foreword to Harvard's annual survey by Philip Kurland, was its expressed resentment over the claim of political scientists that constitutional law is within the scope of their discipline. My answer to Kurland's contemptuous remark that he is not yet ready to turu constitutional law over to the political scientists is simply that, as a political scientist, I am not yet ready to turn the field over to 
lawyers, certainly not to lawyers who would deny the Supreme Court any legitimate political role. The Supreme Court is a branch of the national government, and, as such, it shares part of the responsibility for governing. It is entitled to be judged by the people on the basis of how well it fulfills that responsibility, not on the basis of how little it makes law.

The ideal expressed in the phrase, "government of laws, and not of men," is a meaningful and useful standard for judging the legal order. It loses its meaning, however, if it is read literally. Laws exist, at best, in the form of words, and words cannot govern. Only men, interpreting the words, can perform that function. What the ideal instead repudiates is arbitrariness-the kind of arbitrariness that Frankfurter spoke of when he declared in his Terminiello [ $v$. Chicago, 337 U.S. 1, 11 (1949)] dissent: "We do not sit like a kadi under a tree dispensing justice according to considerations of individual expediency." To state that law is political is not to assert that it may be based on whim or caprice, or judicial will, or individual expediency. The public may properly demand that law be based on reason, but reason is not limited to the application of precedent. It was neither arbitrariness nor lack of reason that led the Court to discard Plessy v. Ferguson [163 U.S. 537 (1896)] or Colegrove v. Green [329 U.S. 549 (1946)], for example, and it is neither arbitrariness nor lack of reason that causes the Court to be influenced by questions of public policy. Of course, bricfs could not be written on the premise that judicial decisions will be arbitrary, but there is a great amount of room between the Blackstonian theory and simple arbitrariness, and it is far from impossible that "a government of laws" can be well served by a politically sensitive judiciary.

Professor Dean Alfange, Jr.

Department of Government and Law

Lafayette College

VI

\section{Question 1}

Since the Supreme Court deals in such significant measure with the ordinary political conversation of the people, it is small wonder that in the press and in the popular imagination it has a frmer place than that of "private law" courts. But I think that the high esteem the Court enjoys is a precarious status. Should it step on too popular a toe, the esteem will be soon dissipated. Nevertheless, and this is what makes the Court remarkable, even those who may be opposed to its results will sometimes come to its aid because they are awed by its vestigial function as the only Olympus in American life; e.g., defense of the Court hy Walter Craig of the American Bar Association during the Goldwater campaign, the defense by some New Dealish groups of the Court in the court-packing battle.

\section{Question 2}

I don't think it would hurt the Court in the slightest if people generally adhered to the beliefs of the "legal realists" because the legal realists didn't believe anything except that judges didn't belicve what they said. I think alienation and non-commitment are such majoritarian attitudes in our national life that emphasis on the fact that judges are motivated by extra-legal factors would, in the final analysis, not really startle anybody. The layman doesn't care what courts do but only what they decide. That what they decide is not inevitably compelled is not widely known but $I$ think it should he.

As in so many areas, that which everybody knows has not yet been reduced to empirical monotony. I daresay it soon will be. I for one am hardly inclined to await passionately the day when social scientists publish answers, the nature of which has usually been suggested by the questions. The real need for empirical research is not to find out flabbly facts as to what pcople think about the Court, contingent as that 
must necessarily be, but to do some serious thinking on how we can give the rich yield of social science data we now possess to the Supreme Court and its bar so that it will be usable and meaningful.

\section{Question 3}

This question is impossible to answer since there is no such thing as a "public." There are various elites with their various concerns and to the extent that they are affected by the Court they are well aware of its workings.

Thurman Arnold is quite right. The trouble with extra-legal materials as an essential confessed element in Supreme Court adjudication is that they simply do not cohere within the existing structure of the Court. See the discussion about the use of social science materials in the School Segregation Cases. If the frankest possible aware of the character of the Court as a political institution is sought, then the frankest re-thinking of the inutility of the adversary process must be engaged in. If politics, economics, psychology and other arts are the real living juices of the Court's work then perhaps non-lawyers should argue the cases before the court. Indeed, perhaps the adversary process should be abandoned. If one is not ready to abandon it, as I am not, then I think one should not expect lawyers to jump too far out of their legal skins. At least if one expects it, one is bound to be disappointed.

Jerome A. Barron

Associate Professor of Law

George Washington University Law School

VII

\section{Question 1}

I would say that the basis of the high esteem in which the Supreme Court is held by the general American public is compounded of several factors: (a) the public need for a firm, central "father-image," which in our form of government is divided between the President, the Court and certain Senators; (b) the mystery surrounding the Courtmystery in the sense that the general public cannot and will not understand its opinions and functions; (c) the constant repetition in text books and newspapers of the glamour of the Court-the pictures of the nine robed Justices, the publicity attending certain Justices from time to time, the reiterations of the fact that they are at the apex of our judicial system, etc., etc. All of these factors combine to make the Court an integral part of our folklore of secular infallibility that is seemingly essential to a stable form of government. State courts and trial courts are too localized, too fragmented, and too close to the people to share in this public esteem.

\section{Question 2}

I don't think the Court as an institution is either aided or harmed by the public's "adherence" to any particular legal beliefs, realist or otherwise. It is a mirage to say that the general public has any discernible comprehension of the beliefs of the legal realists or of the judicial restraint school. The public thinks of and reacts to the Court in gross political terms, usually of awe or of derision. To the extent that it is possible to guess, I would imagine those terms are more of a "realist" nature but I can't escape feeling that the beliefs of the legal realists are beyond the pale of public comprehension. I know of no empirical studies of this nature, hotwever.

\section{Question 3}

I firmly believe there is no valid basis for keeping from the public any view of the judicial process, including the legal realistic view. Every view is entitled to public airing; and the more that is written about the ways of Supreme Court adjudication the better. But the nature of this subject is such that only a tiny fraction of the public, in addition to the intellectually sophisticated, will ever read or be influenced 
by such revelations. To get to the public, such revelations must appear in newspapers or popular periodicals like Reader's Digest or Life. But the numbers of people who actually read and absorb material in such popular form are infinitesimally small. They are so few, in fact, that I can see no real purpose served in discussing whether the public should be made aware of the legal realist view. That view is so sophisticated that it will continue to be confined for the most part to intellectual or legal circles, with occasional but not too significant public airings.

In conclusion I would say that, to the extent there is meaningful public revelation of the legal realist viewpoint, the Court will not suffer in public esteem. The legal realist concept is much nearer than any other to the actual operation of the Court and indeed is more consistent with a public understanding of the Court's functions. The public myth of the Court as an Olympian tribunal may remain, but the myth is made more meaningful once it is understood that the Court actually moves in political and practical paths.

\title{
Eugene Gressman
}

Attorney-at-Law

\begin{abstract}
VIII
Question 1

The Supreme Court is venerated because it is the apex, the pinnacle.

It is elementary psychology, it seems to me, that Americans always admire and praise anything that is the best of its kind, or the topmost of its kind, even if it isn't very good. Thus H. L. Mencken tells us (with his remarkable insight and inimitable style),
\end{abstract}

Here, as always, the worshipper is the father of the gods, and no less when they are evil than when they are benign. The inferior man must find himself superiors, that he may marvel at his political equality with them, and in the absence of recognizable superiors de facto he creates them de jure.

And so the godship of the Court is fathered by the public that they may marvelno less if the Court is evil than if it is benign.

Clearly the same kind of psychology obtains with other public officials of all sorts and levels. Public opinion polls are often published in which people are asked what occupation they regard as most prestigious; the answer is always "Justice of the Supreme Court"-not of some lower court. But the element of "I know the great man and I'm just as good as he is" extends to all levels of officialdom. Today $I$ was at lunch with a retired Judge of the Superior Court. All of the waiters wanted to reach across the counter and shake hands with him, and say "Hello, Your Honor," and got great and genuine pleasure from doing so. Seated next to us was the manager of the main office of a large bank. The waiters all addressed him by name, but paid no further attention to him. He probably makes four times as much money as the judge ever got as judge, and wields forty times as much power as the judge ever had.

\section{Question 2}

As usual, I go back to Holmes.

The question is, do judges really have power to legislate only interstitially-are they confined from molar to molecular motion?

I submit not; at least that they have not so confined themselves in recent years.

The turning-point came, I think, when the court, walking on eggs in the School Segregation Cases, found that its public image was such that it could get away with revolutionary changes in the doctrines. The success that it had in that field must have encouraged it mightily to take the other revolutionary changes in the areas of criminal-Jaw enforcement and reapportionment. Obviously they liave been successful 
in those areas too in obtaining public acceptance and legislative-judicial enforcement of doctrines that are law only because nine men, or a majority of them, think they are right. I think Douglas in his WE, THE JuDGEs [(1956)] quoted somebody as saying, "Power is a heady thing, my boy." And so it is.

Obviously, then, if the general public-and especially minor public functionaries (I am thinking particularly of state legislators)-felt that they could get across to the general public the ideas of the legal realists (that the Emperor has not got any clothes on) then the Court as an institution would be immeasurably harmed in the sense that its power would be much curtailed. If the fiat of the Court were to be critically examined for its public acceptability, then the Court would not be nearly so powerful as it is.

Moreover, the Court's public image is sustained and fostered each time it has one of the successes such as it had in the areas of school segregation, criminal-law enforcement, and reapportionment. Success begets success; more power begets more power.

This makes the Court much more able and much more willing to legislate in other areas that are not so "important" legally-because they do not involve constitutional questions-but may be much more important practically and economically. I speak of the rewriting of statutes, especially regulatory and economic statutes. Theoretically, "If Congress does not like our legislation, it can repeal it-as it has done a number of times in the past." (Jackson, J., concurring in United States v. PUC, 345 U.S. 295, 320-21 (1953)). But does this not become immeasurably more difficult for Congress to do when the public image of the Court is such that a Congressman who votes to overrule the Court-even when the Court has trodden on an area which constitutionally belongs to Congress-will inevitably be charged with sacrilege? (Compare Senator Dirksen on school prayer.)

\section{Question 3}

It seems to me that the "legal realist" view of the judicial process is unquestionably valid, but there is no way ever to make it known to the public, even if you wanted to. It is not a question of revealing to the public something which is known to an intellectual elite. It is a question of ever getting the public to see the obvious. Mencken concludes the article quoted above by saying,

The one permanent emotion of the inferior man, as of all the simpler mammals, is fear-fear of the unknown, the complex, the inexplicable. What he wants beyond everything else is security. His instincts incline him toward a society so organized that it will protect him at all hazards, and not only against perils to his hide but also against assaults upon his mind-against the need to grapple with unaccustomed problems, to weigh ideas, to think things out for himself, to scrutinize the platitudes upon which his everyday thinking is based.

People will applaud Willie Mays every time he hits another home run, and they will continue to venerate the Supreme Court, regardless of what you try to teach them. Both are part of the national mystique. The Supreme Court, Jackie Kennedy, movie stars, and champion athletes, will be in the same position in the minds of the public until you and I are dust, and longer. I should add astronauts.

Arnold is of course quite mistaken, and there are plenty of legal realists around who write briefs on quite a different basis. A lot of them are in the Solicitor General's office and they write briefs every day on the premise that this is a government of men and not of laws. They sometimes invite the Court to make new law on the basis of a newspaper article. (I can give an example or two if desired.)

I haven't any idea what a survey of Solicitor General's briefs would show; but I suspect that the quickest way to debunk Arnold's statement would be to review all of the briefs filed in one term by the Solicitor's office, or even review all of the briefs filed in two or three terms by Arnold's firm. An even quicker, although perhaps not so convincing, way would be simply to go to Stern \& Gressman (both of whom are ex- 
functionaries of the Solicitor General's office) and read in there [STERN \&: GressmaN, SUPREME COURT PRACTICE (1950)] that argument in the Supreme Court is different from argument elsewhere.

Illustrations of the truth of-and the lack of complete insight in-the quotation in Mislkin's footnote 25 [Mishkin, The Supreme Court, 1964 Term, 79 HARv. L. REv. 56, $62 \mathrm{n.25}$ (1965)] ... are within everybody's experience. Many a disappointed litigant has accused the particular judge of venality or dishonesty or stupidity, and many a one has announced, "I'll take the case to the Supreme Court of the United States." None lias ever announced-except Senator Dirksen-that he would take the case from the Supreme Court to the people.

And so it is quite true to say that "to the 'ipse dixit' of a court, however just or impartial, men are not so constituted as to afford the same ready obedience and respect," but the problem is that every man is ready to believe that he has been subjected to the ipse dixit of a trial court, but they always think that the Supreme Court is infallible because it is final, and therefore "willingly acquiesce." (Not so, of course, some of the soplisticated "instituitonal litigants" referred to by Mishkin; but to them, Congress is available, as in the bank merger act. 